\title{
Acceleration of Aryl-Zinc Formation and its Enantioselective Addition to Aldehydes by Microwave Irradiation and Aziridine-2-Methanol Catalysts
}

Antonio L. Braga, ${ }^{a *}$ Marcio W. Paixao, ${ }^{a, b}$ Bernhard Westermann, ${ }^{b}$ Paulo H. Schneider ${ }^{c}$ and Ludger A. Wessjohann ${ }^{\text {b* }}$

aDepartamento de Química, Universidade Federal de Santa, Santa Maria, Brazil. Fax: +55 553220 8998; Tel: +55 5532208761 E-mail: albraga@mail.ufsm.br

${ }^{b}$ Leibniz Institute of Plant Biochemistry, Bioorganic Chemistry, Weinberg 3, 06120 Halle, Germany. Fax: 49345 55821309; Tel: 49345 55821301; E-mail:

wessjohann@ipb-halle.de

'Instituto de Química, Universidade Federal do Rio Grande do Sul, Porto Alegre, Brazil; Tel: +55 5133167211

\section{SUPPORTING INFORMATION}

\section{Table of Contents}

Materials and Methods

General Procedure for the synthesis of ligand 1

Selected Characterization of 1

General Procedure for the synthesis of ligand $\mathbf{2}$

Selected Characterization of 2

General Procedure for the synthesis of ligand 3a-c

Selected Characterization of $\mathbf{3 a}$

Selected Characterization of $\mathbf{3 b}$

S6

Selected Characterization of $\mathbf{3 c}$ S6

${ }^{1} \mathrm{H}$ NMR $\left(400 \mathrm{MHz}, \mathrm{CDCl}_{3}\right)$ Spectrum of 1 
${ }^{13} \mathrm{C}$ NMR $\left(100 \mathrm{MHz}, \mathrm{CDCl}_{3}\right)$ Spectrum of $1 \quad$ S8

${ }^{1} \mathrm{H}$ NMR $\left(300 \mathrm{MHz}, \mathrm{CDCl}_{3}\right)$ Spectrum of $2 \quad$ S9

${ }^{13} \mathrm{C} \mathrm{NMR}\left(75 \mathrm{MHz}, \mathrm{CDCl}_{3}\right)$ Spectrum of $2 \quad$ S9

${ }^{1} \mathrm{H}$ NMR $\left(300 \mathrm{MHz}, \mathrm{CDCl}_{3}\right)$ Spectrum of 3a $\quad \mathbf{S 1 0}$

${ }^{13} \mathrm{C}$ NMR $\left(75 \mathrm{MHz}, \mathrm{CDCl}_{3}\right)$ Spectrum of 3a $\quad \mathbf{S 1 0}$

${ }^{1} \mathrm{H}$ NMR $\left(300 \mathrm{MHz}, \mathrm{CDCl}_{3}\right)$ Spectrum of 3b $\quad \mathbf{S 1 1}$

${ }^{13} \mathrm{C}$ NMR $\left(75 \mathrm{MHz}, \mathrm{CDCl}_{3}\right)$ Spectrum of $\mathbf{3 b} \quad \mathbf{S 1 1}$

${ }^{1} \mathrm{H}$ NMR $\left(300 \mathrm{MHz}, \mathrm{CDCl}_{3}\right)$ Spectrum of 3c $\quad \mathbf{S 1 2}$

${ }^{13} \mathrm{C}$ NMR $\left(75 \mathrm{MHz}, \mathrm{CDCl}_{3}\right)$ Spectrum of $3 \mathrm{c} \quad \mathbf{S 1 2}$

General procedure for the asymmetric arylation of aldehydes. $\quad \mathbf{S 1 3}$

$\begin{array}{ll}\text { For reactions performed without microwave irradiation. } & \mathbf{S 1 3}\end{array}$

$\begin{array}{ll}\text { For reactions performed under microwave irradiation. Method A } & \mathbf{S 1 3}\end{array}$

$\begin{array}{ll}\text { For reactions performed under microwave irradiation. Method B } & \text { S13 }\end{array}$

${ }^{1} \mathrm{H}$ NMR (400 MHz, $\mathrm{CDCl}_{3}$ ) Spectrum of (4-methyphenyl)phenylmethanol $\quad \mathbf{S 1 5}$

${ }^{13} \mathrm{C} \mathrm{NMR}\left(100 \mathrm{MHz}, \mathrm{CDCl}_{3}\right.$ ) Spectrum of (4-methyphenyl)phenylmethanol $\quad \mathbf{S 1 5}$

${ }^{1} \mathrm{H}$ NMR (400 MHz, $\mathrm{CDCl}_{3}$ ) Spectrum of (2-methyphenyl)phenylmethanol $\quad \mathbf{S 1 6}$

${ }^{13} \mathrm{C}$ NMR $\left(100 \mathrm{MHz}, \mathrm{CDCl}_{3}\right.$ ) Spectrum of (2-methyphenyl)phenylmethanol $\quad \mathbf{S 1 6}$

${ }^{1} \mathrm{H}$ NMR (400 MHz, $\mathrm{CDCl}_{3}$ ) Spectrum of (4-chlorophenyl)phenylmethanol $\quad \mathbf{S 1 7}$

${ }^{13} \mathrm{C} \mathrm{NMR} \mathrm{(100} \mathrm{MHz,} \mathrm{CDCl}_{3}$ ) Spectrum of (4-chlorophenyl)phenylmethanol $\quad \mathbf{S 1 7}$

${ }^{1} \mathrm{H}$ NMR (400 MHz, $\mathrm{CDCl}_{3}$ ) Spectrum of (2-chlorophenyl)phenylmethanol $\quad \mathbf{S 1 8}$

${ }^{13} \mathrm{C}$ NMR $\left(100 \mathrm{MHz}, \mathrm{CDCl}_{3}\right)$ Spectrum of (2-chlorophenyl)phenylmethanol $\quad \mathbf{S 1 8}$

Authentic racemic of Phenyl(p-tolyl)methanol using Chiralcel OD as column. $\quad$ S20

Chiral phase HPLC chart of Phenyl(p-tolyl)methanol with catalyst 1 (Table 1, S20 entry 1).

Chiral phase HPLC chart of Phenyl(p-tolyl)methanol with catalyst 2 (Table 1, S21 entry 2). 
Authentic racemic of Phenyl(p-tolyl)methanol using Chiralcel OD-H as column. S22

Chiral phase HPLC chart of Phenyl(p-tolyl)methanol with catalyst 3a (Table 1, S22 entry 3).

Chiral phase HPLC chart of Phenyl(p-tolyl)methanol with catalyst 3a under S23 microwave irradiation (Methold A, Table 2, entry 1).

Chiral phase HPLC chart of Phenyl(p-tolyl)methanol with catalyst 3a under $\mathbf{S 2 3}$ microwave irradiation (Methold A, Table 2, entry 2).

Chiral phase HPLC chart of Phenyl(p-tolyl)methanol with catalyst 3a under S24 microwave irradiation (Methold A, Table 2, entry 3 ).

Chiral phase HPLC chart of Phenyl(p-tolyl)methanol with catalyst 3a under S24 microwave irradiation (Methold A, Table 2, entry 4).

Authentic racemic of Phenyl(p-tolyl)methanol using Chiralcel OB-H as column. S25

Chiral phase HPLC chart of Phenyl(p-tolyl)methanol with catalyst 3a under $\quad$ S25 microwave irradiation (Methold B, Table 2, entry 6).

Chiral phase HPLC chart of Phenyl(p-tolyl)methanol with catalyst 3a under microwave irradiation (Methold B, Table 2, entry 7).

S26

Chiral phase HPLC chart of Phenyl(p-tolyl)methanol with catalyst 3a under microwave irradiation (Methold B, Table 2, entry 8).

Chiral phase HPLC chart of Phenyl(p-tolyl)methanol with catalyst 3a under microwave irradiation (Methold B, Table 2, entry 9). 
Materials and Methods. All microwave irradiation experiments were carried out in a dedicated Personal Chemistry microwave apparatus model Emrys ${ }^{\mathrm{TM}}$ Knowledge Builder. The instrument consists of a continuous focused microwave power delivery system with operator selectable power output from 0-300 W. In all experiments the microwave power and the temperature were held constant to ensure reproducibility. Reactions were carried out in $10-\mathrm{mL}$ glass tubes, sealed with aluminum/Teflon crimp tops, which can be exposed up to $250^{\circ} \mathrm{C}$ and 20 bar internal pressure. The specified reaction time corresponds to the total irradiation time. Temperature was measured with an IR sensor on the outer surface of the process vial. After the irradiation period, the reaction vessel was cooled rapidly $(60-120 \mathrm{~s})$ to ambient temperature by air jet cooling. ${ }^{1} \mathrm{H}$ NMR and ${ }^{13} \mathrm{C}$ NMR spectra were recorded at $300 \mathrm{MHz}$ and $75 \mathrm{MHz}$ or at $400 \mathrm{MHz}$ and $100 \mathrm{MHz}$, respectively on a commercial spectrometer. Chemical shifts $(\delta)$ are reported in ppm relative to the TMS $\left({ }^{1} \mathrm{H}\right.$ NMR) and to the solvent $\left({ }^{13} \mathrm{C}\right.$ NMR). Mass spectra were obtained using a commercial instrument with an electrospray ionization source (ESIMS). Flash column chromatography was carried out using Merck silica gel 60 (0.015-0.040 nm) and analytical thin layer chromatography (TLC) was performed using commercial silica gel $60 \mathrm{~F}_{254}$ aluminum sheets. All commercially available chemicals were used without further purification.

Preparation of ligand 1. Valine methyl ester hydrochloride $(5 \mathrm{mmol})$ was added in small portions to freshly prepared $\mathrm{EtMgBr}$ reagent $(25 \mathrm{mmol})$ in THF (25 $\mathrm{mL} .1 \mathrm{M}$ solution) at $0{ }^{\circ} \mathrm{C}$ under an argon atmosphere. The reaction was stirred at room temperature for $12 \mathrm{~h}$, before being quenched by pouring into $2 \mathrm{M} \mathrm{NaOH}$. The heterogeneous mixture was filtered through a pad of Celite and washed with dichloromethane $(3 \times 50 \mathrm{~mL})$. The combined organic phases were dried with $\mathrm{MgSO}_{4}$, filtered and the solvent removed under reduced pressure. The amino alcohol is dissolved in acetonitrile and diiodoalkane, and $\mathrm{K}_{2} \mathrm{CO}_{3}$ was added subsequently. The mixture was refluxed for $24 \mathrm{~h}$, filtered, and the solvent evaporated. The residue was dissolved in dichloromethane, dried over $\mathrm{MgSO}_{4}$, 
filtered, and the solvent removed under vacuum and the crude product was purified by flash chromatography on silica with hexanes/ethyl acetate (90:10) as eluent.

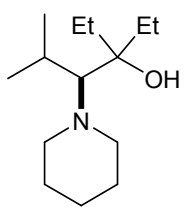

(S)-3-Ethyl-5-methyl-4-(piperidin-1-yl)hexan-3-ol.(1) Pale yellow oil, Yield: $92 \%$; $[\alpha]_{D}{ }^{20}+25.0$ (c $\left.1.0 \mathrm{EtOAc}\right) ;{ }^{1} \mathrm{H}$ NMR $\left(\mathrm{CDCl}_{3}, 400 \mathrm{MHz}\right): \delta$ 2.92-2.91 (m, 2H), 2.67-2.65 (m, 2H), 2.21-2.19 (m, 1H), 2.02-1.99 (m, $2 \mathrm{H}), 1.88-1.69(\mathrm{~m}, 2 \mathrm{H}), 1.57-1.43(\mathrm{~m}, 6 \mathrm{H}), 1.43-1.31(\mathrm{~m}, 1 \mathrm{H}), 1.06-0.84(\mathrm{~m}, 12 \mathrm{H})$; ${ }^{13} \mathrm{C} \mathrm{NMR}\left(\mathrm{CDCl}_{3}, 100 \mathrm{MHz}\right): \delta 74.2,73.1,52.8,29.2,28.6,28.2,27.2,24.7,23.8$, 22.3, 8.1, 7.8; HRMS-ESI $\mathrm{m} / \mathrm{z}$ calcd for $\mathrm{C}_{14} \mathrm{H}_{29} \mathrm{NO}+\mathrm{H}^{+} 228.2321$, found 228.2320.

Preparation of ligand 2. $\mathrm{PhMgBr}(20 \mathrm{mmol})$ in THF (20 mL, $1 \mathrm{M}$ solution) was added to a THF $(10 \mathrm{~mL})$ solution of Proline $\mathrm{N}$-Boc methyl ester $(5 \mathrm{mmol})$ at 0 ${ }^{\circ} \mathrm{C}$, and the mixture was stirred for additional $4 \mathrm{~h}$, before being poured into $2 \mathrm{M}$ $\mathrm{NaOH}$. The heterogeneous mixture was filtered through a pad of Celite and washed with dichloromethane $(3 \times 50 \mathrm{~mL})$. The combined organic phases were dried with $\mathrm{MgSO}_{4}$, filtered and the solvent removed under vacuum. The resulting product was used without further purification. The product was dissolved in THF $(30 \mathrm{~mL})$ and was cooled to $0{ }^{\circ} \mathrm{C}$. Lithium aluminum hydride $(0.759 \mathrm{~g}, 10 \mathrm{mmol})$ was added to the solution in several portions, and the mixture was refluxed for $2 \mathrm{~h}$. After the mixture was cooled to $0{ }^{\circ} \mathrm{C}$, water was added. The mixture was acidified to $\mathrm{pH}$ 3 with $1 \mathrm{M} \mathrm{HCl}$, washed with dichloromethane, and made alkaline with concentrated aqueous $\mathrm{NaOH}$. The precipitate was filtered off and extracted with ethyl acetate. The organic layer was separated, and the filtrate was extracted again with dichloromethane. The combined extracts were dried over $\mathrm{MgSO}_{4}$. The solvent was removed under vacuum and the crude product was purified by flash chromatography on silica with hexanes/ethyl acetate (90:10) as solvent.

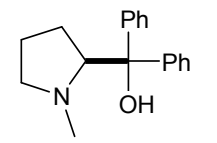

(S)-1-Methylpyrrolidin-2-yl diphenylmethanol (2): Yield: 83\%; mp $68.5-68.9{ }^{\circ} \mathrm{C} ;[\alpha]^{20} \mathrm{D}+19\left(\mathrm{c} 1.2, \mathrm{CH}_{2} \mathrm{Cl}_{2}\right) .{ }^{1} \mathrm{H} \mathrm{NMR}\left(400 \mathrm{MHz}, \mathrm{CDCl}_{3}\right)$ : $\delta=7.63-7.61(\mathrm{~m}, 2 \mathrm{H}) ; 7.53-7.51(\mathrm{~m}, 2 \mathrm{H}) ; 7.25-7.21(\mathrm{~m}, 4 \mathrm{H}) ; 7.10-7.09(\mathrm{~m}, 2 \mathrm{H})$; 4.54 (bs, $1 \mathrm{H}) ; 3.61-3.58(\mathrm{~m}, 1 \mathrm{H}) ; 3.09-3.07(\mathrm{~m}, 1 \mathrm{H}) ; 2.43-2.37(\mathrm{~m}, 1 \mathrm{H}) ; 1.87-1.79$ 
$(\mathrm{m}, 4 \mathrm{H}) ; 1.68-1.57(\mathrm{~m}, 3 \mathrm{H}) .{ }^{13} \mathrm{C}$ NMR $\left(100 \mathrm{MHz}, \mathrm{CDCl}_{3}\right): \delta=148.2 ; 146.6 ; 127.9$; $126.0 ; 125.4 ; 125.3 ; 77.3 ; 71.9 ; 59.0 ; 42.9 ; 29.8 ; 23.9$. HRMS-ESI: $\mathrm{m} / \mathrm{z}$ calcd for $\mathrm{C}_{18} \mathrm{H}_{21} \mathrm{NO}+\mathrm{H}^{+}: 268.1701$; found: $\mathrm{C}_{18} \mathrm{H}_{21} \mathrm{NO}+\mathrm{H}^{+}: 268.1696$.

Preparation of ligands 3. The Grignard reagent $(25 \mathrm{mmol}$,) in THF (8.4 $\mathrm{mL}, 3 \mathrm{M}$ solution) was added dropwise over a period of $10 \mathrm{~min}$ to a solution of the appropriate aziridine ester $(5 \mathrm{mmol})$ in $10 \mathrm{~mL}$ of THF. After $1.5 \mathrm{~h}$ the reaction was quenched with saturated aqueous $\mathrm{NH}_{4} \mathrm{Cl}(30 \mathrm{ml})$ followed by the evaporation of the organic solvents. The residue was extracted with diethyl ether $(3 \times 50 \mathrm{ml})$ and the combined organic layers were dried $\left(\mathrm{MgSO}_{4}\right)$ and concentrated to give the product. The crude product was purified by flash column chromatography on silica (hexanes-ethyl acetate, 12:1); $\mathrm{NEt}_{3}$ was added to the eluent to prevent detritylation of the product during the purification procedure. Recrystallisation was achieved from $\mathrm{MeOH}-\mathrm{NEt}_{3}$ by a hot solution.

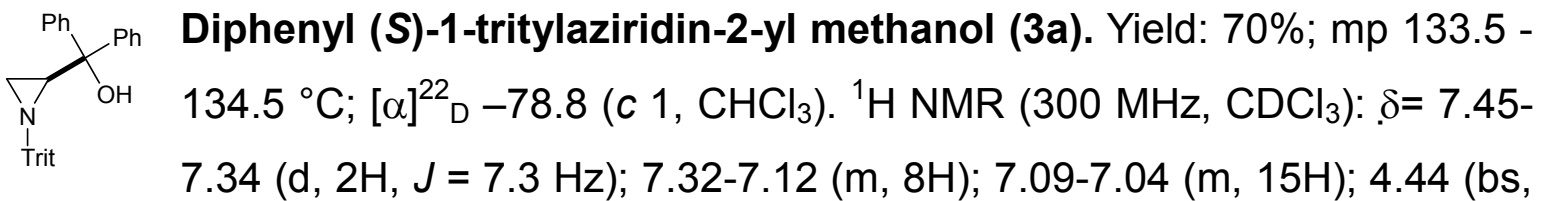
$1 \mathrm{H}) ; 2.38(\mathrm{dd}, 1 \mathrm{H}, J=6.2,3.1 \mathrm{~Hz}) ; 2.08(\mathrm{~d}, 1 \mathrm{H}, J=3.1 \mathrm{~Hz}) ; 1.32(\mathrm{~d}, 1 \mathrm{H}, J=6.2$ $\mathrm{Hz}) ;{ }^{13} \mathrm{C}$ NMR $\left(75 \mathrm{MHz}, \mathrm{CDCl}_{3}\right): \delta=146.7 ; 145.2 ; 143.4 ; 129.0 ; 127.7 ; 127.5$; $127.2 ; 126.6 ; 126.5 ; 126.5 ; 126.0 ; 125.7,73.9,73.8,41.4$, 23.8. HRMS-ESI: $m / z$ calcd for $\mathrm{C}_{34} \mathrm{H}_{29} \mathrm{NO}+\mathrm{Na}^{+}: 490.2147$; found: $\mathrm{C}_{34} \mathrm{H}_{29} \mathrm{NO}+\mathrm{Na}^{+}: 490.2141$.

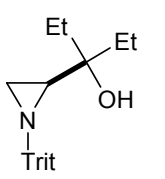

3-[(S)-1-Tritylaziridin-2-yl]pentan-3-ol (3b). Yield: 74\%; Pale yellow oil; $[\alpha]^{22} \mathrm{D}-82.8\left(\mathrm{c} 1, \mathrm{CHCl}_{3}\right) .{ }^{1} \mathrm{H}$ NMR $\left(300 \mathrm{MHz}, \mathrm{CDCl}_{3}\right): \delta=7.51-7.18(\mathrm{~m}$, $15 \mathrm{H}) ; 3.05$ (bs, $1 \mathrm{H}) ; 1.94$ (d, $1 \mathrm{H}, J=3.3 \mathrm{~Hz}) ; 1.62-1.43(\mathrm{~m}, 1 \mathrm{H}) ; 1.41-$ $1.29(\mathrm{~m}, 4 \mathrm{H}) ; 1.14(\mathrm{~d}, 1 \mathrm{H}, J=6.4 \mathrm{~Hz}) ; 0.73(\mathrm{q}, 6 \mathrm{H}, J=7.5 \mathrm{~Hz}) ;{ }^{13} \mathrm{C} \mathrm{NMR}(75 \mathrm{MHz}$, $\left.\mathrm{CDCl}_{3}\right): \delta=144.0 ; 129.3 ; 127.4 ; 126.7,73.9,70.8,40.1,31.9 ; 28.2 ; 23.5 ; 8.1 ; 7.73$. HRMS-ESI: $\mathrm{m} / \mathrm{z}$ calcd for $\mathrm{C}_{26} \mathrm{H}_{29} \mathrm{NO}+\mathrm{Na}^{+}: 394.2141$; found: $\mathrm{C}_{26} \mathrm{H}_{29} \mathrm{NO}+\mathrm{Na}^{+}$: 394.2147 


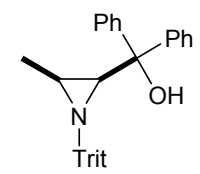

((2-S,3-S)-3-Methyl-1-tritylaziridin-2-yl)diphenylmethanol

(3c). Yield: 82\%; mp $174-176{ }^{\circ} \mathrm{C} ;[\alpha]^{22}{ }_{\mathrm{D}}+22\left(\mathrm{c} 1, \mathrm{CHCl}_{3}\right) .{ }^{1} \mathrm{H}$ NMR $(300$ $\left.\mathrm{MHz}, \mathrm{CDCl}_{3}\right): \delta=7.46-6.98(\mathrm{~m}, 25 \mathrm{H}) ; 3.05(\mathrm{~s}, 1 \mathrm{H}) ; 2.20(\mathrm{~d}, 1 \mathrm{H}, J=6.7$ $\mathrm{Hz}) ; 1.66(\mathrm{q}, 1 \mathrm{H}, J=6.0 \mathrm{~Hz}) ; 1.19(\mathrm{~d}, 3 \mathrm{H}, J=5.8 \mathrm{~Hz}) ;{ }^{13} \mathrm{C} \mathrm{NMR}\left(75 \mathrm{MHz}, \mathrm{CDCl}_{3}\right)$ : $\delta=148.4 ; 146.0 ; 143.8 ; 143.7,129.3 ; 128.6 ; 127.8 ; 127.7 ; 127.2 ; 126.7 ; 126.6$; 126.0; 125.5, 75.1, 73.5, 45.2, 31.9, 13.7. HRMS-ESI: $\mathrm{m} / \mathrm{z}$ calcd for $\mathrm{C}_{35} \mathrm{H}_{31} \mathrm{NO}+$ $\mathrm{Na}^{+}: 504.2303$; found: $\mathrm{C}_{35} \mathrm{H}_{31} \mathrm{NO}+\mathrm{Na}^{+}: 504.2297$. 

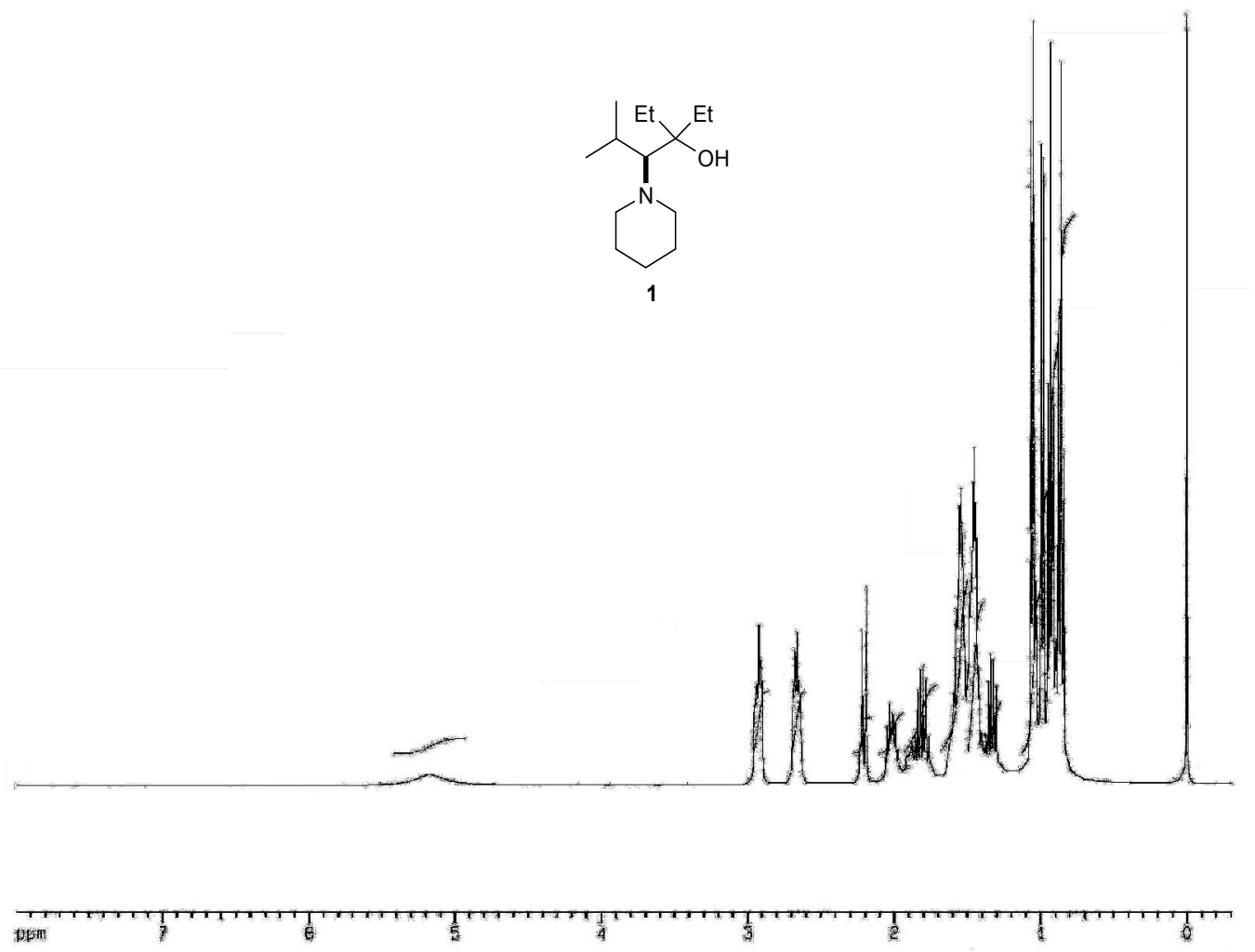

${ }^{1} \mathrm{H}$ NMR $\left(400 \mathrm{MHz}, \mathrm{CDCl}_{3}\right)$ Spectrum of 1

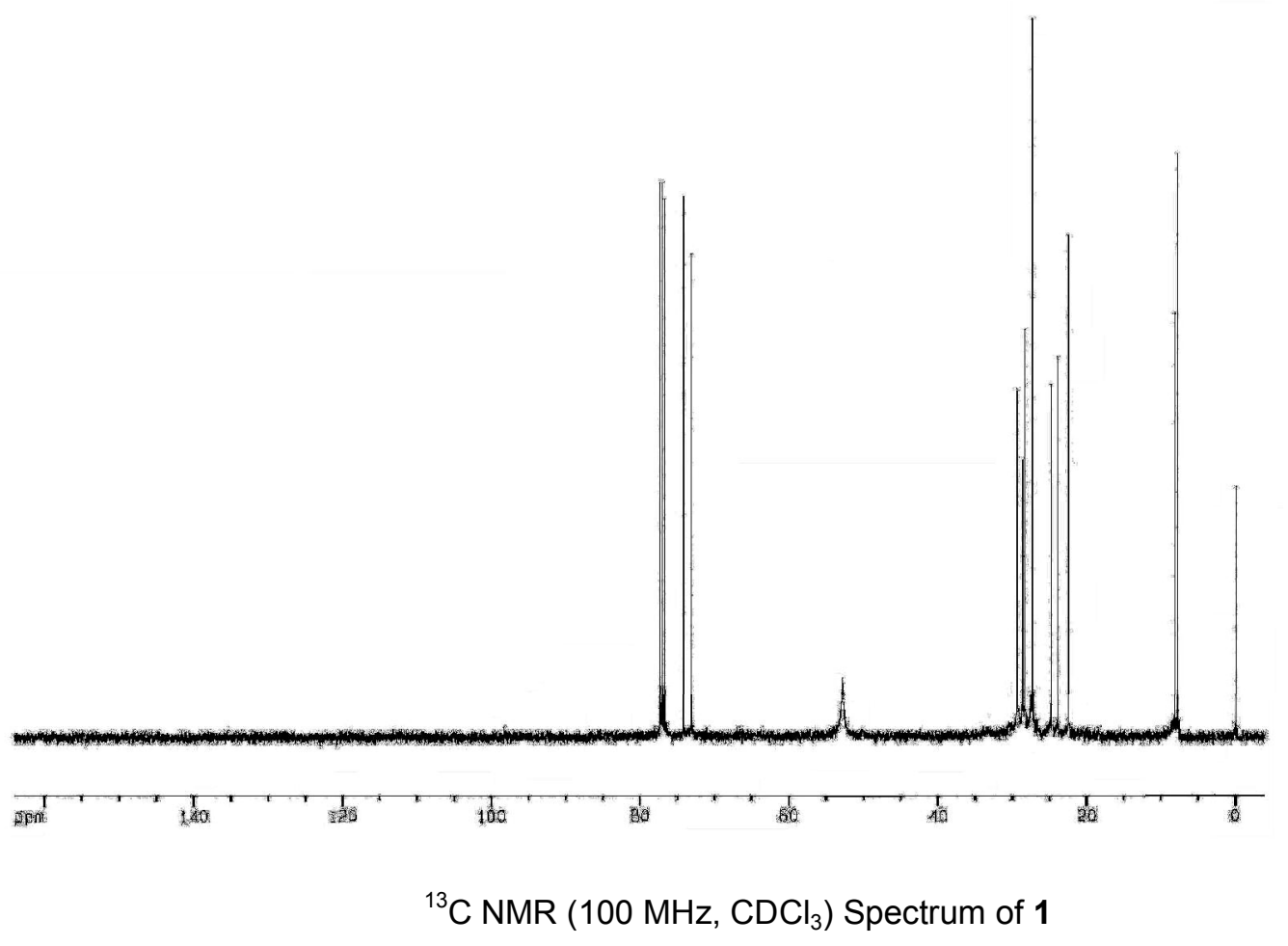



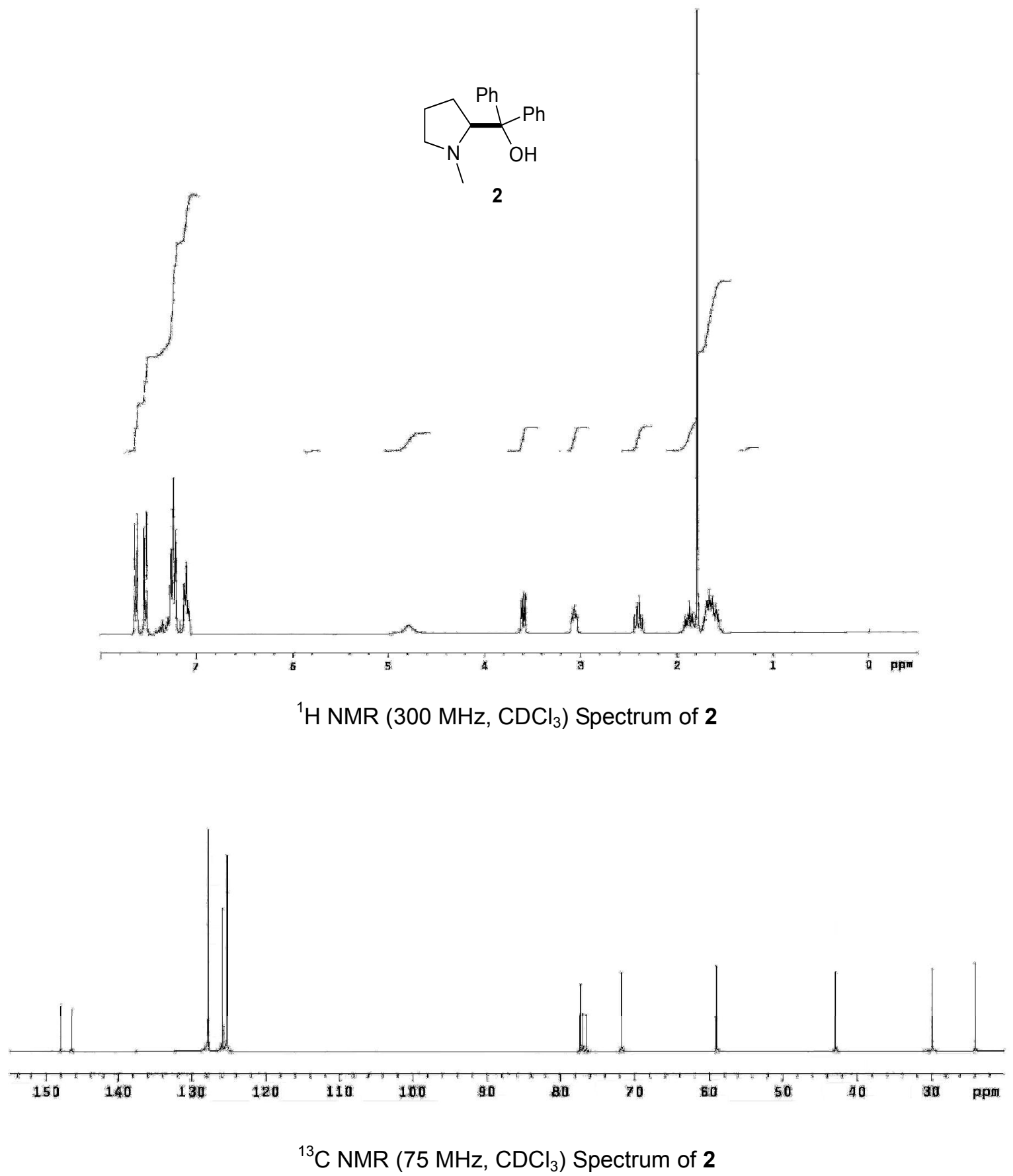

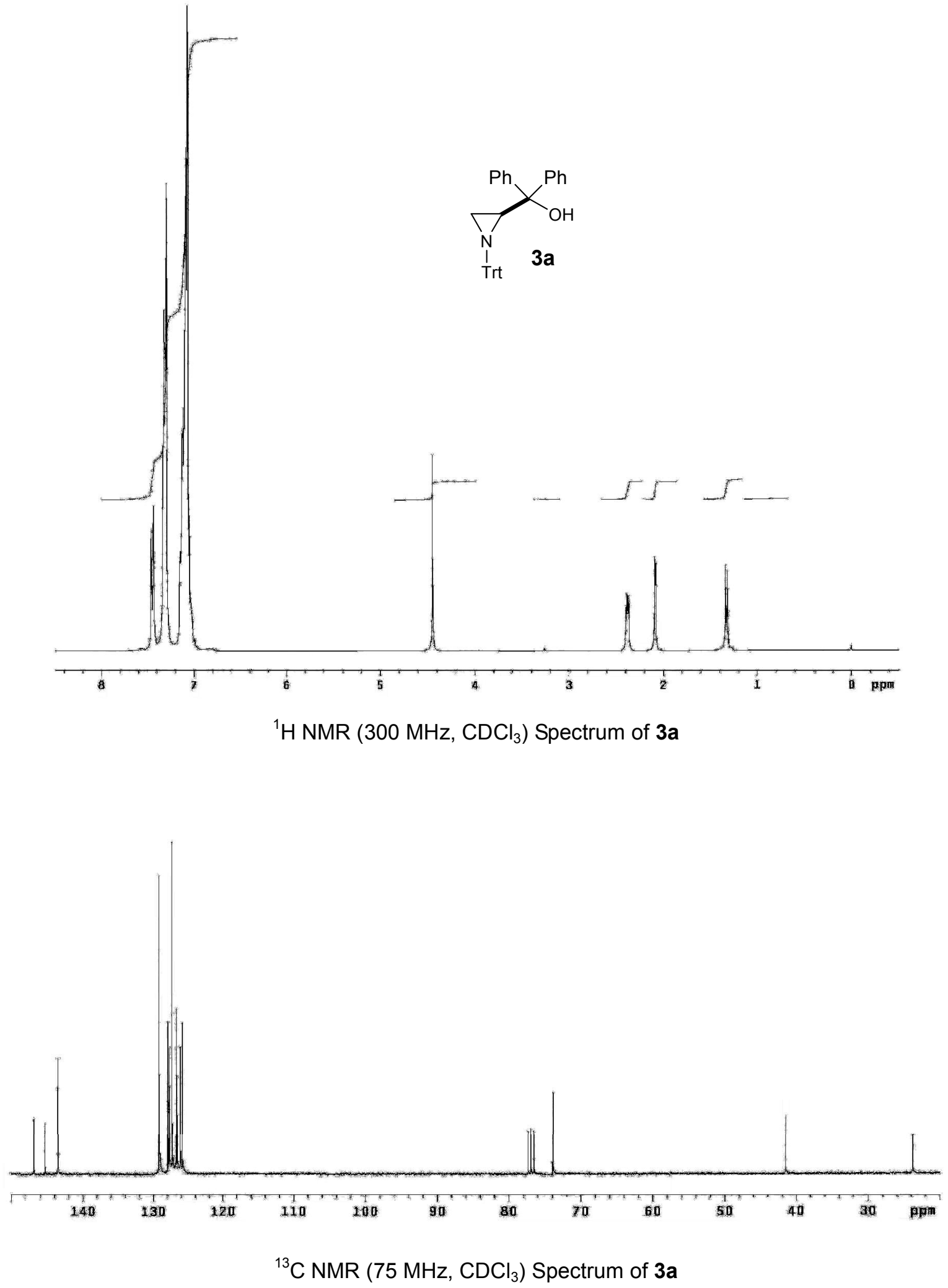

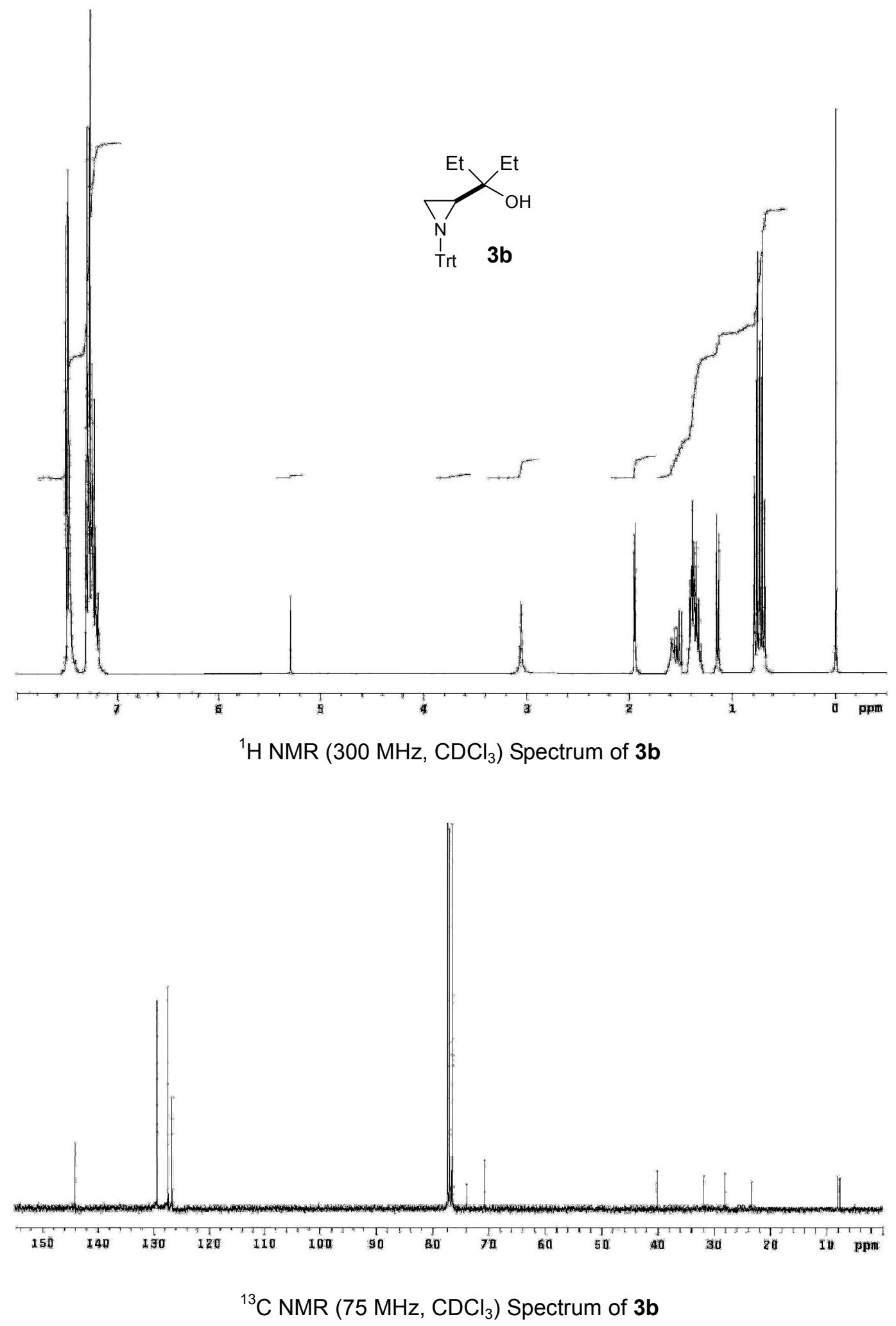

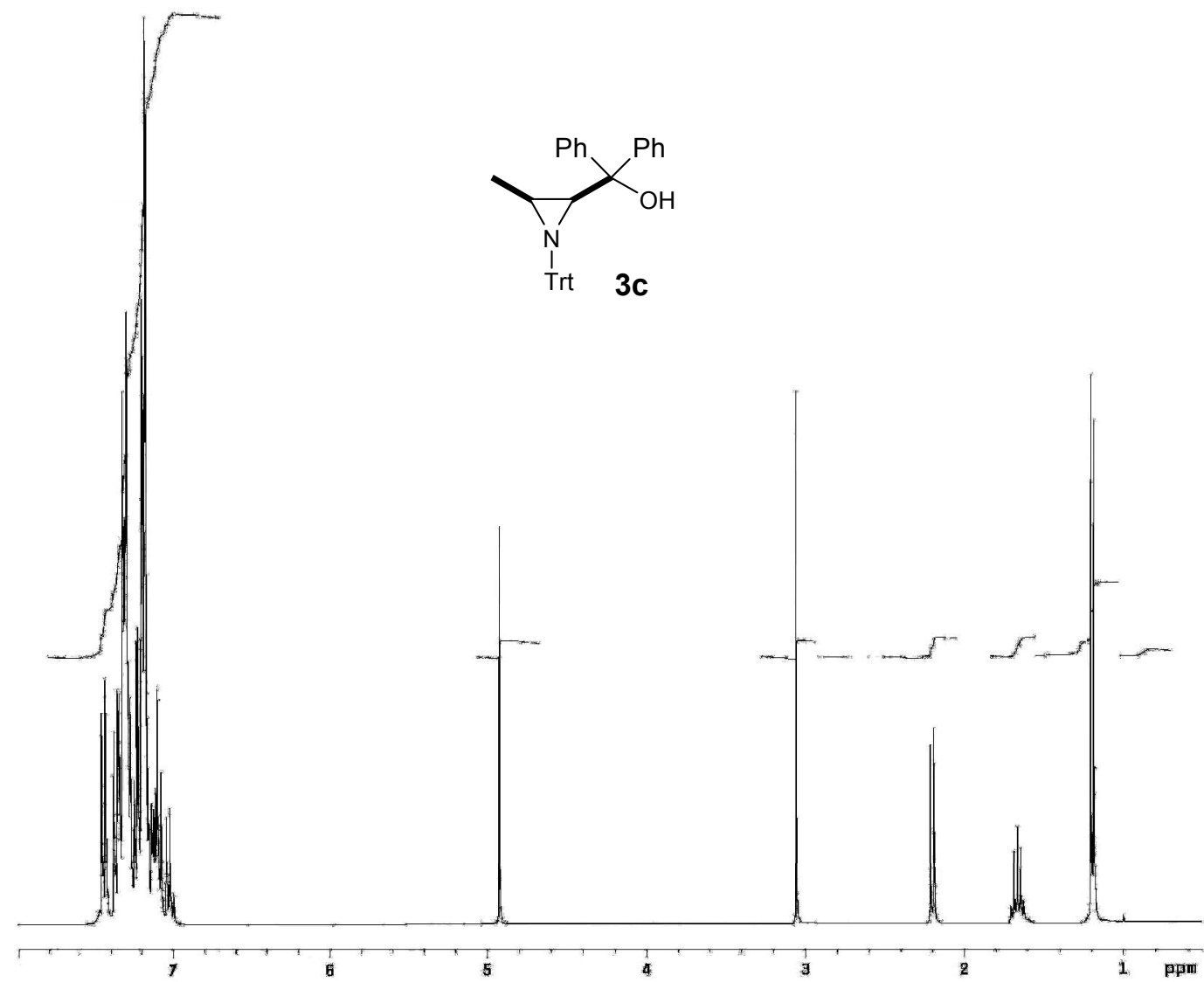

${ }^{1} \mathrm{H}$ NMR $\left(300 \mathrm{MHz}, \mathrm{CDCl}_{3}\right)$ Spectrum of 3c

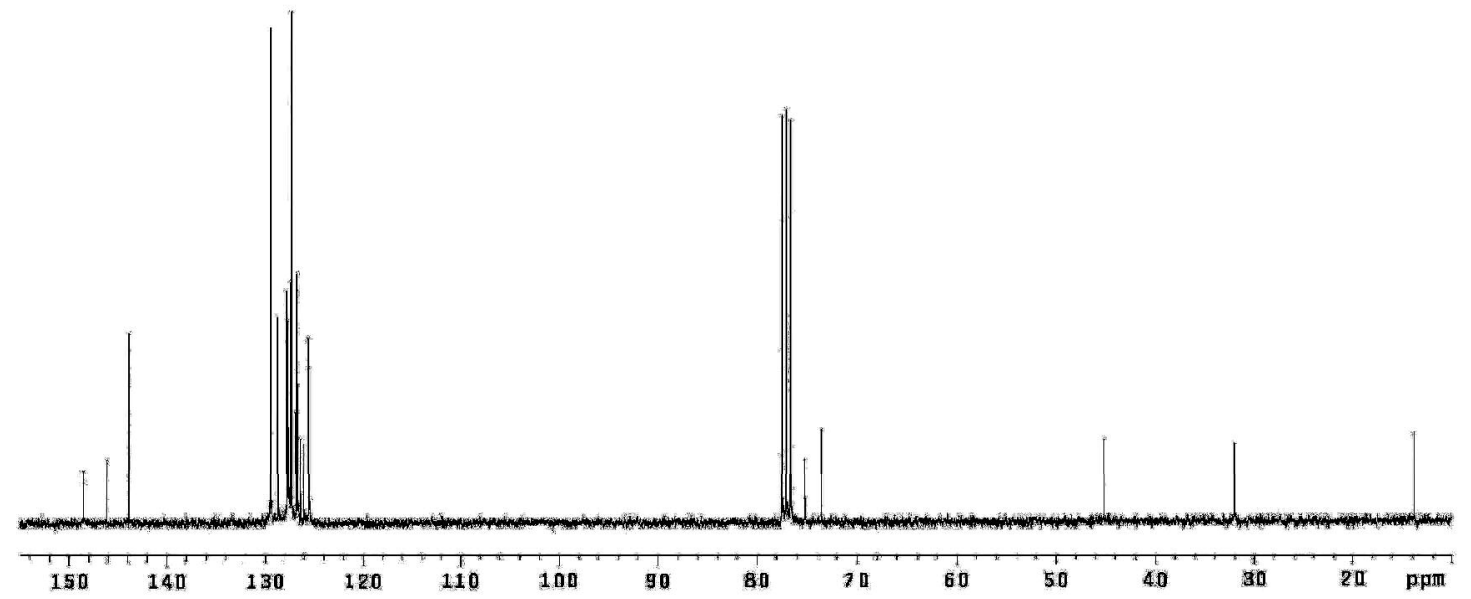

${ }^{13} \mathrm{C}$ NMR $\left(75 \mathrm{MHz}, \mathrm{CDCl}_{3}\right)$ Spectrum of 3c 


\section{General procedure for the asymmetric arylation of aldehydes.}

1) For reactions performed without microwave irradiation. (Table 1) Diethylzinc (3.6 mmol, toluene solution) was added dropwise to a solution of boronic acid $(1.2 \mathrm{mmol})$ in toluene $(2 \mathrm{~mL})$ under an argon atmosphere. After stirring for $12 \mathrm{~h}$ (Time 1 ) at $60{ }^{\circ} \mathrm{C}$, the mixture is cooled to room temperature and a solution of the chiral amino alcohol $(10 \mathrm{~mol} \%)$ in $1 \mathrm{~mL}$ of toluene was added. The reaction is stirred for $15 \mathrm{~min}$ and a solution of aldehyde $(0.5 \mathrm{mmol})$ in toluene was subsequently added. After stirring overnight (Time 2 ) the reaction was quenched with water and the aqueous layer was extracted with dichloromethane. The organic phase was dried over $\mathrm{MgSO}_{4}$, filtered and the solvents evaporated under reduced pressure. Purification by flash chromatography on silica eluting with a mixture of hexane/ethyl acetate (90:10) afforded the pure diarylmethanols.

\section{2) For reactions performed under microwave irradiation.}

2.1) Method A. Diethylzinc (1.8 mmol, toluene solution) was dropwise added to a solution of phenyl boronic acid $(0.6 \mathrm{mmol})$ in toluene $(1 \mathrm{~mL})$ under an argon atmosphere in a sealed vessel. After stirring for $12 \mathrm{~h}$ (Time 1) at $60^{\circ} \mathrm{C}$, the mixture was cooled to room temperature and a toluene solution of the chiral amino alcohol (10 mol\%) in $1 \mathrm{~mL}$ of toluene was added. The reaction is stirred for additional 15 min and the aldehyde $(0.25 \mathrm{mmol})$ solution was added subsequently. The reaction vessel was irradiated at $300 \mathrm{~W}$ and heated to $60{ }^{\circ} \mathrm{C}$ for a given time (Time 2, Table 2). After cooling, the reaction mixture was quenched with water and the aqueous layer was extracted with dichloromethane. The combined organic layers were dried over $\mathrm{MgSO}_{4}$, filtered and the solvents evaporated under reduced pressure. Purification by flash chromatography on silica eluting with a mixture of hexanes/ethyl acetate (90:10) afforded the pure diarylmethanols.

2.2) Method B. Diethylzinc (1.8 mmol, toluene solution) was added dropwise

to a solution of phenyl boronic acid $(0.6 \mathrm{mmol})$ in toluene $(1 \mathrm{~mL})$ under an argon atmosphere in a sealed vessel. The mixture was irradiated for a given time (Time 
1, Table 2) at $60^{\circ} \mathrm{C}$, with an irradiation power of $300 \mathrm{~W}$. A toluene solution of the chiral amino alcohol (10 mol\%) in $1 \mathrm{~mL}$ of toluene was added. The reaction is stirred for $15 \mathrm{~min}$ and the aldehyde $(0.25 \mathrm{mmol})$ solution added subsequently. The reaction vessel was irradiated at $300 \mathrm{~W}$ and heated to $60{ }^{\circ} \mathrm{C}$ for 5 min (Time 2). After cooling, the reaction mixture was quenched with water and the aqueous layer was extracted with dichloromethane. The combined organic layers were dried over $\mathrm{MgSO}_{4}$, filtered, and the solvents evaporated under reduced pressure. Purification by flash chromatography on silica eluting with a mixture of hexanes/ethyl acetate (90:10) afforded the pure diarylmethanols. 


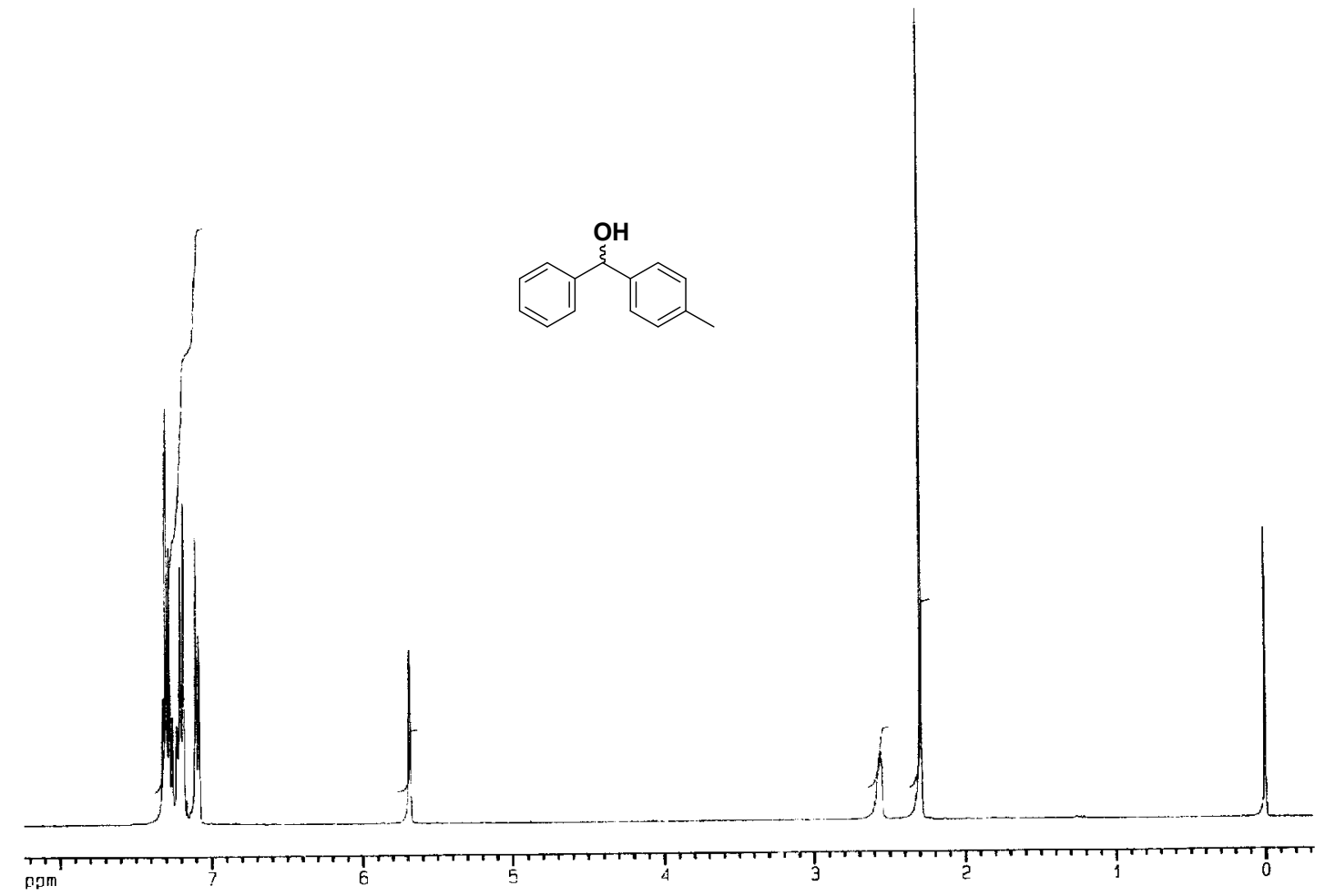

${ }^{1} \mathrm{H}$ NMR (400 MHz, $\mathrm{CDCl}_{3}$ ) Spectrum of (4-methyphenyl)phenylmethanol

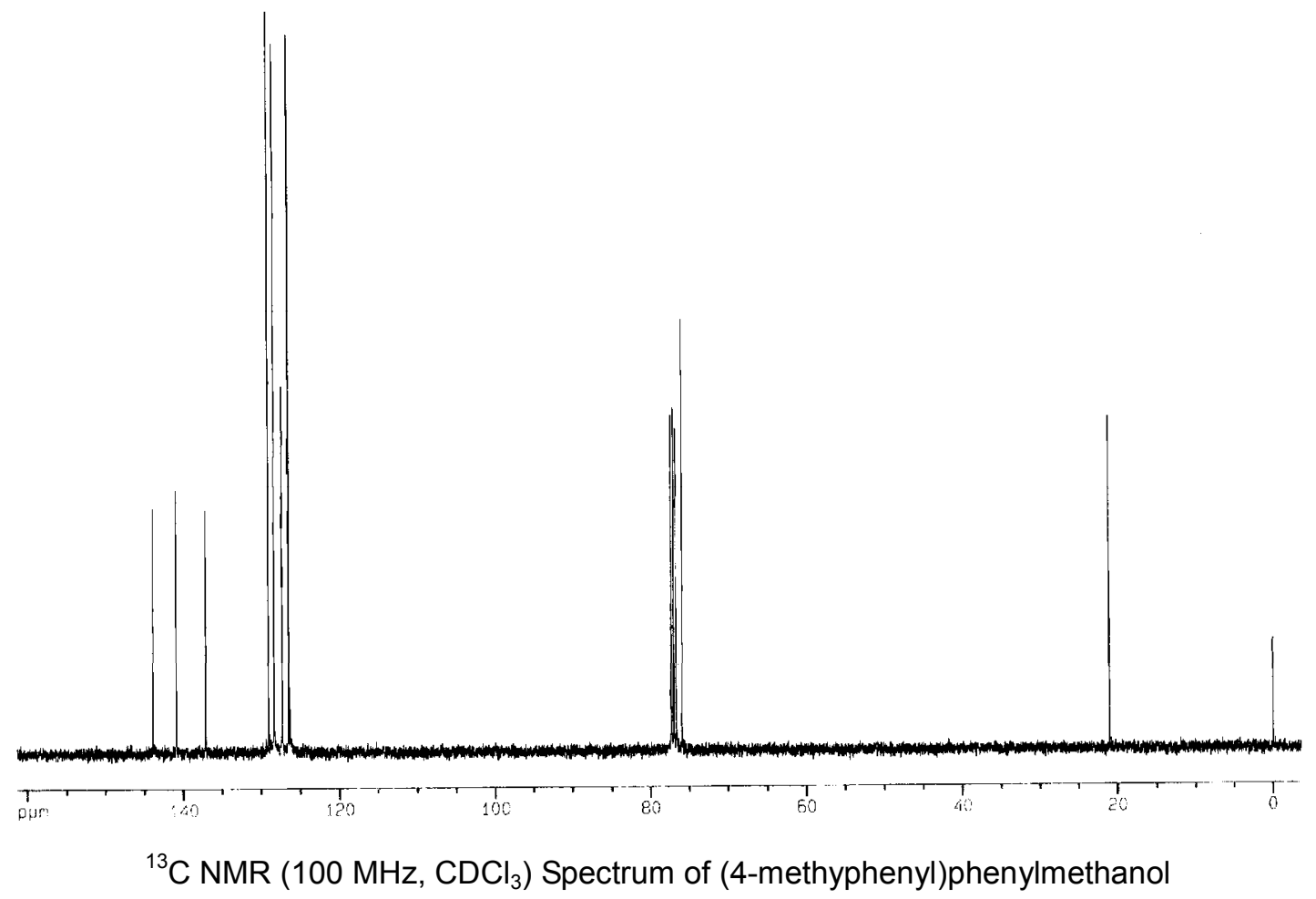




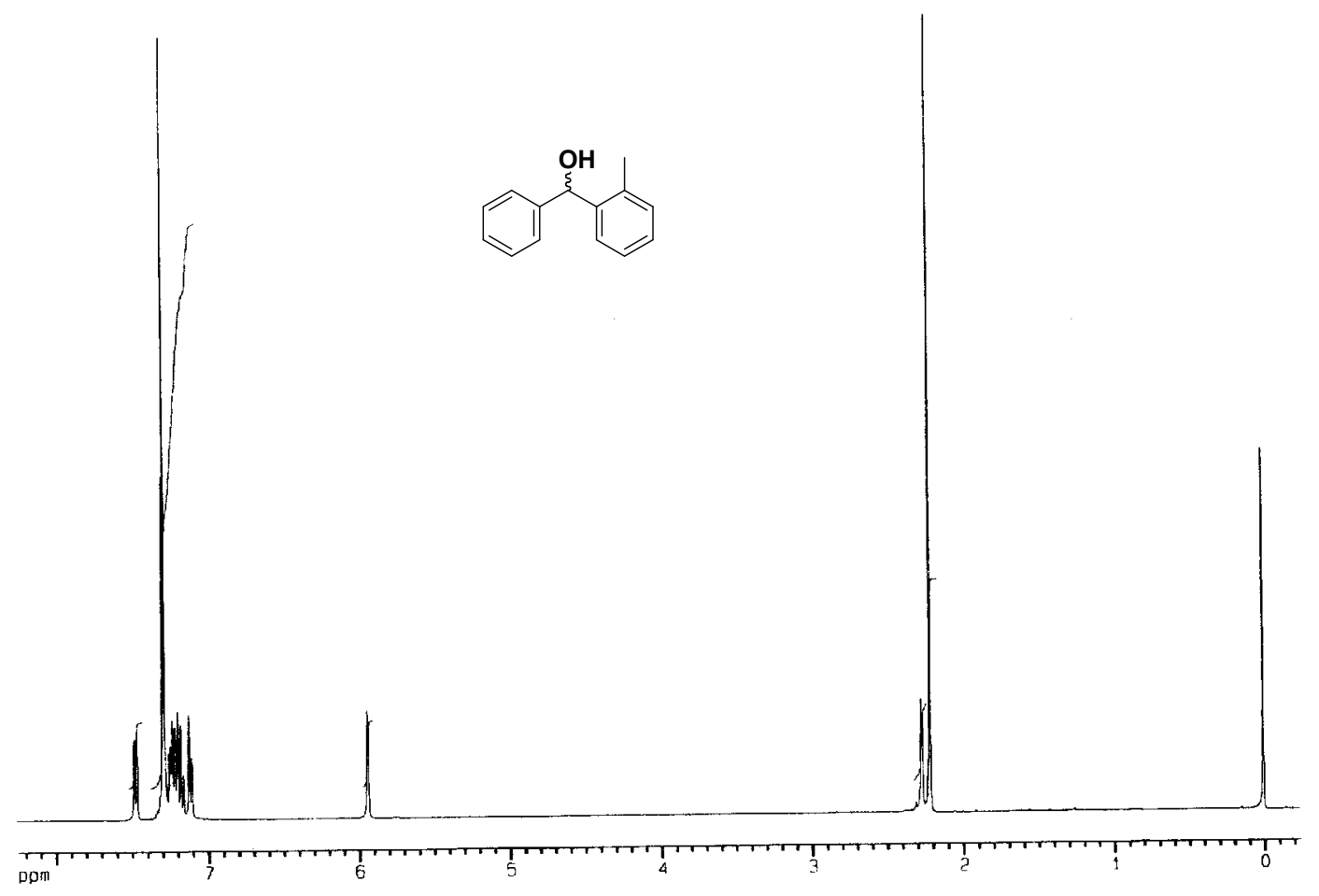

${ }^{1} \mathrm{H} \mathrm{NMR}\left(400 \mathrm{MHz}, \mathrm{CDCl}_{3}\right.$ ) Spectrum of (2-methyphenyl)phenylmethanol

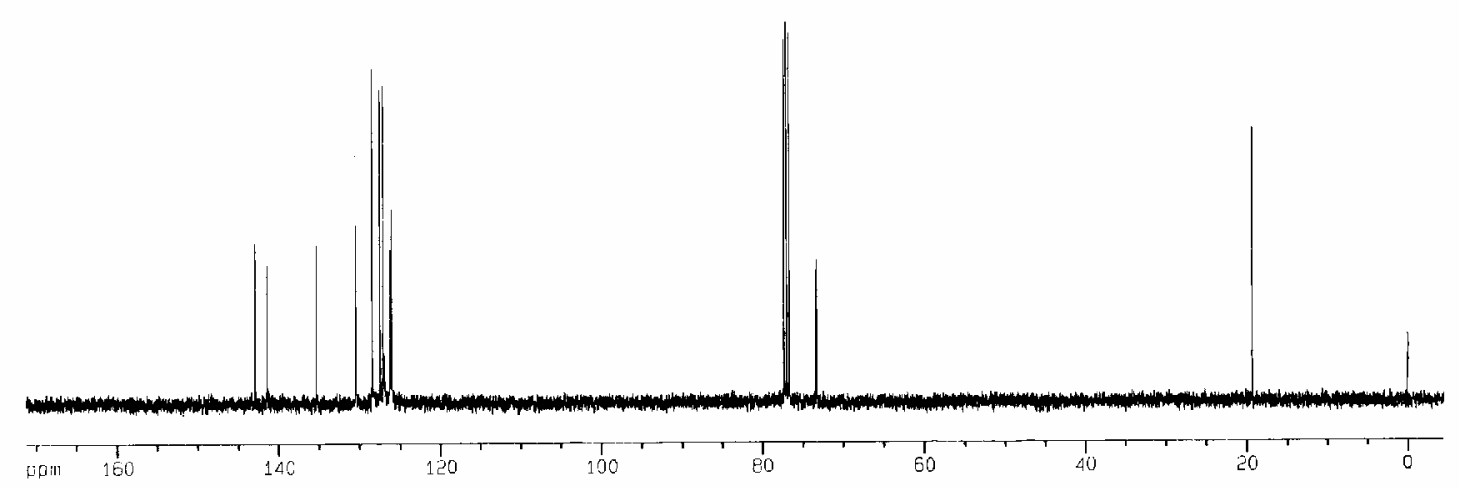

${ }^{13} \mathrm{C} \mathrm{NMR}\left(100 \mathrm{MHz}, \mathrm{CDCl}_{3}\right)$ Spectrum of (2-methyphenyl)phenylmethanol 


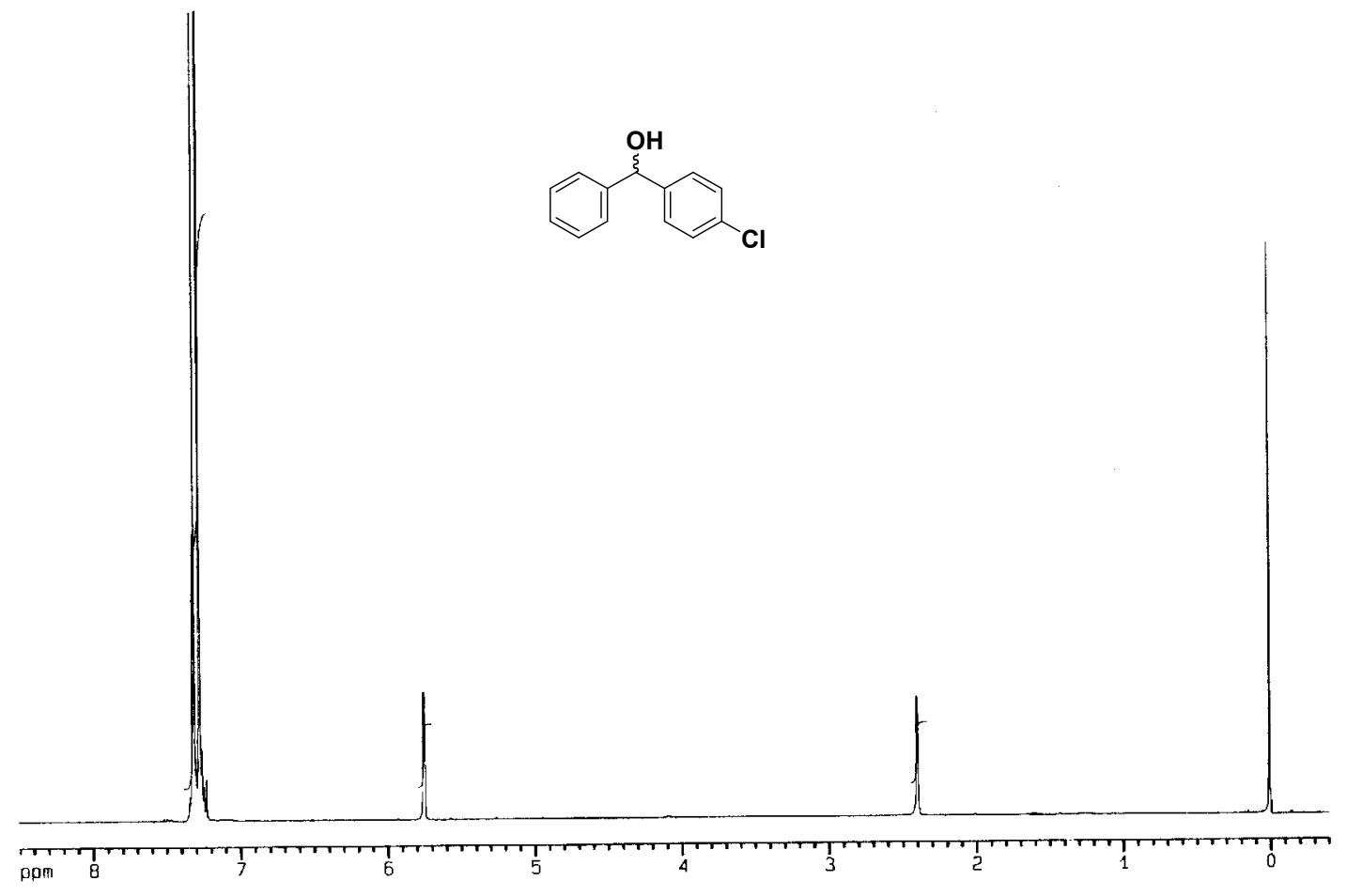

${ }^{1} \mathrm{H}$ NMR $\left(400 \mathrm{MHz}, \mathrm{CDCl}_{3}\right.$ ) Spectrum of (4-chlorophenyl)phenylmethanol

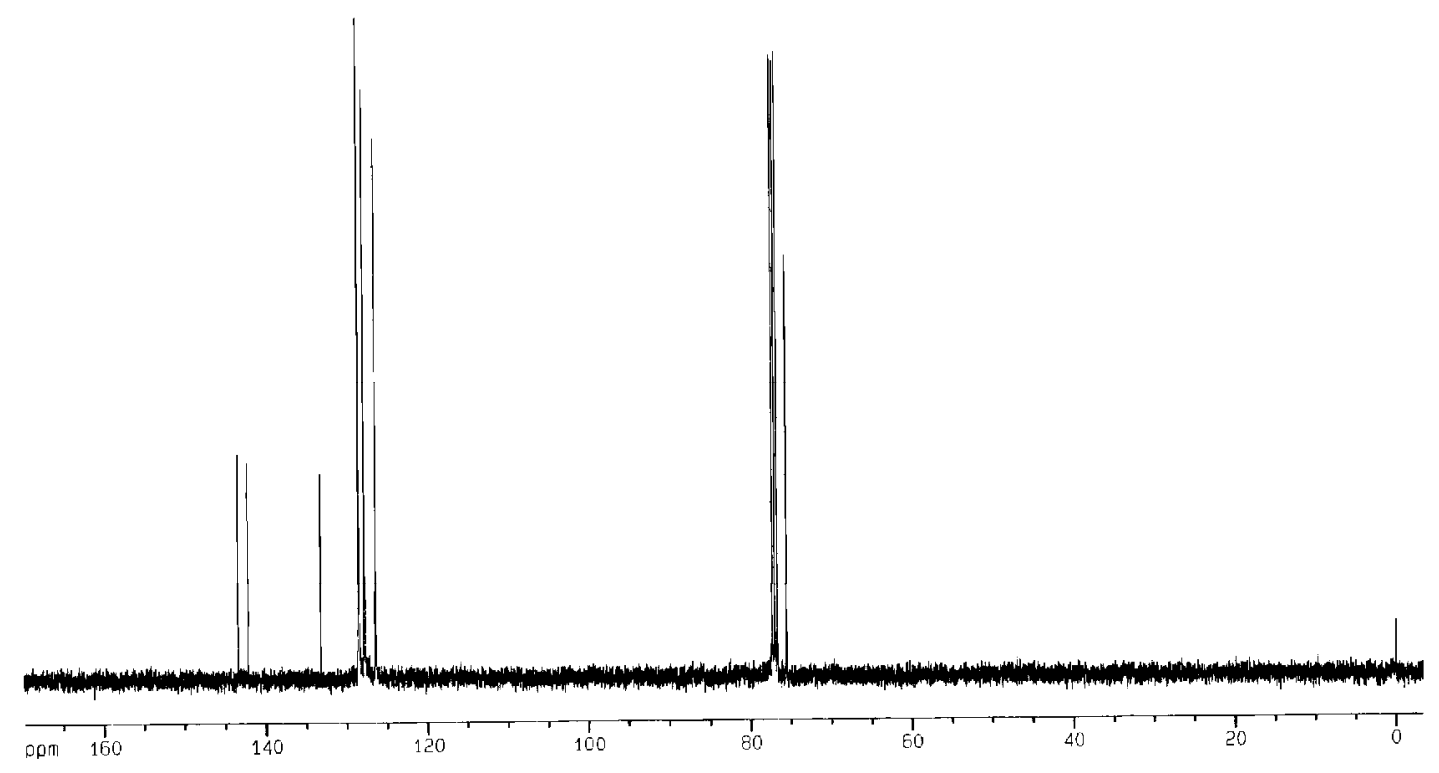

${ }^{13} \mathrm{C}$ NMR (100 MHz, $\mathrm{CDCl}$ ) Spectrum of (4-chlorophenyl)phenylmethanol 


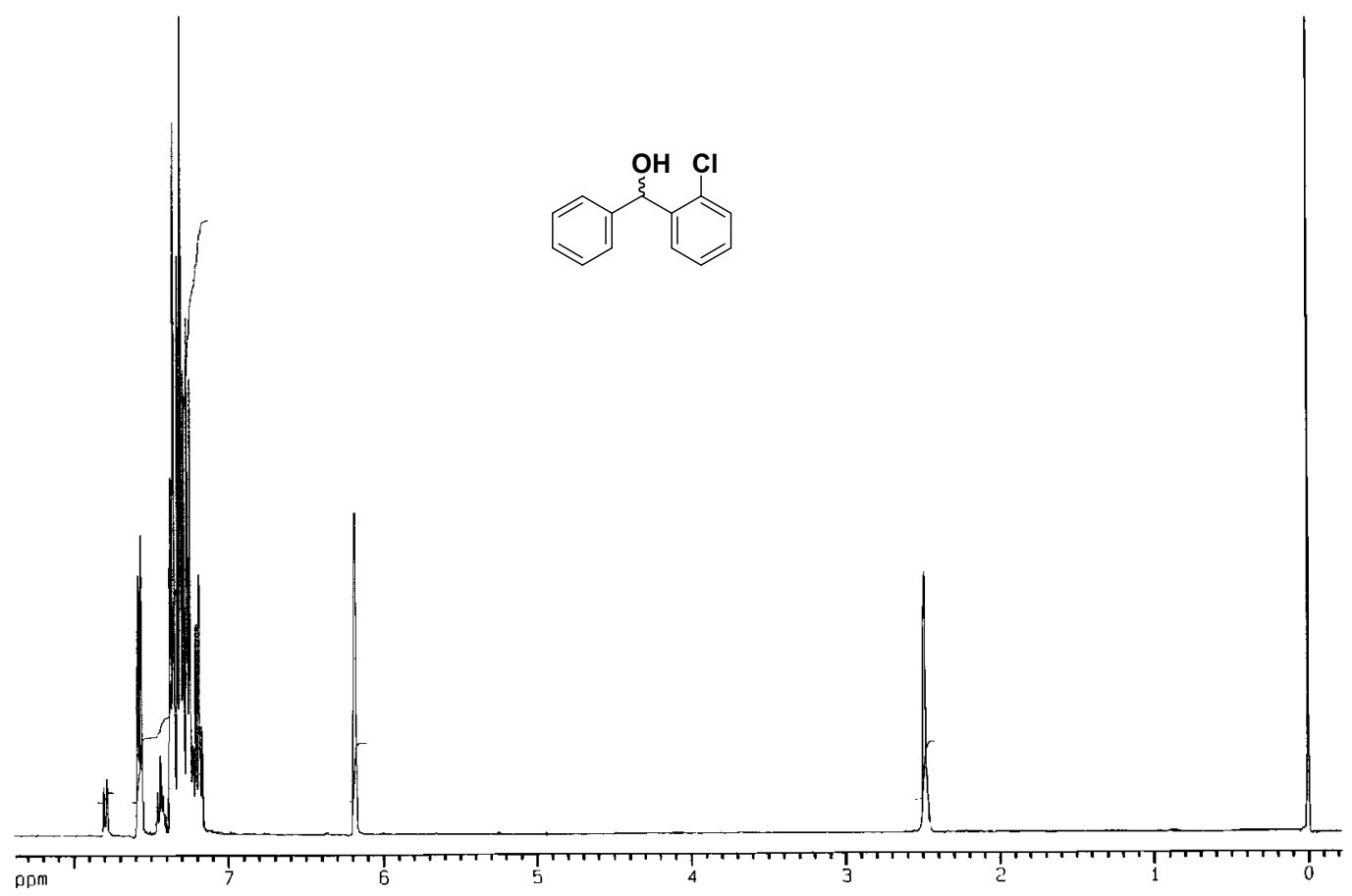

${ }^{1} \mathrm{H}$ NMR $\left(400 \mathrm{MHz}, \mathrm{CDCl}_{3}\right.$ ) Spectrum of (2-chlorophenyl)phenylmethanol

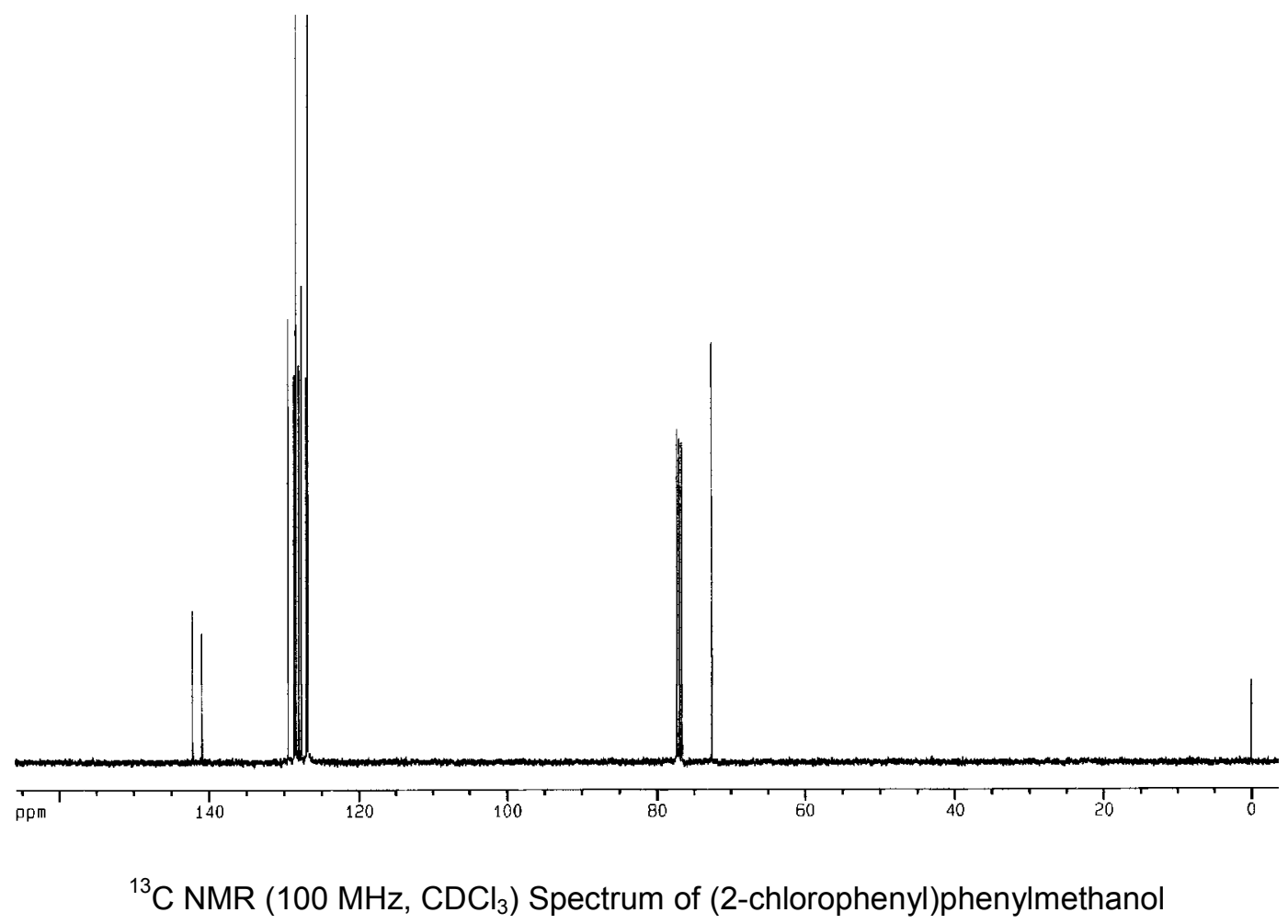


HPLC-Analyses ${ }^{1}$

All measurements were performed at a $20{ }^{\circ} \mathrm{C}$ column temperature using a UV detector at $254 \mathrm{~nm}$.

Phenyl(p-tolyl)methanol:

Chiralcel OD, hexane/i-PrOH 90:10, $0.5 \mathrm{~mL} / \mathrm{min},(S): 19.1 \mathrm{~min},(R): 21.1 \mathrm{~min}$

Chiralcel OD-H, hexane/i-PrOH 90:10, $0.5 \mathrm{~mL} / \mathrm{min},(S): 17.6 \mathrm{~min},(R): 19.9 \mathrm{~min}$

Chiralcel OB-H, hexane/i-PrOH 90:10, $0.5 \mathrm{~mL} / \mathrm{min},(S): 23.5 \mathrm{~min},(R): 27.6 \mathrm{~min}$

Phenyl(o-tolyl)methanol:

Chiralcel OB-H, hexane/i-PrOH 95/5, $1 \mathrm{~mL} / \mathrm{min},(R): 43.9 \mathrm{~min},(S): 56.5 \mathrm{~min}$

(4-Chlorophenyl)(phenyl)methanol::

Chiralpak AD-H, hexane/i-PrOH 90:10, $1 \mathrm{~mL} / \mathrm{min},(R): 13.7 \mathrm{~min},(S): 15.2 \mathrm{~min}$

(2-Chlorophenyl)(phenyl)methanol

Chiralcel OD, hexane/i-PrOH 90:10, $0.5 \mathrm{~mL} / \mathrm{min},(R): 15.9 \mathrm{~min},(S): 19.8 \mathrm{~min}$

\footnotetext{
${ }^{1}$ Bolm, C.: Rudolph, J. J. Am. Chem. Soc. 2002, 124, 14850.
} 


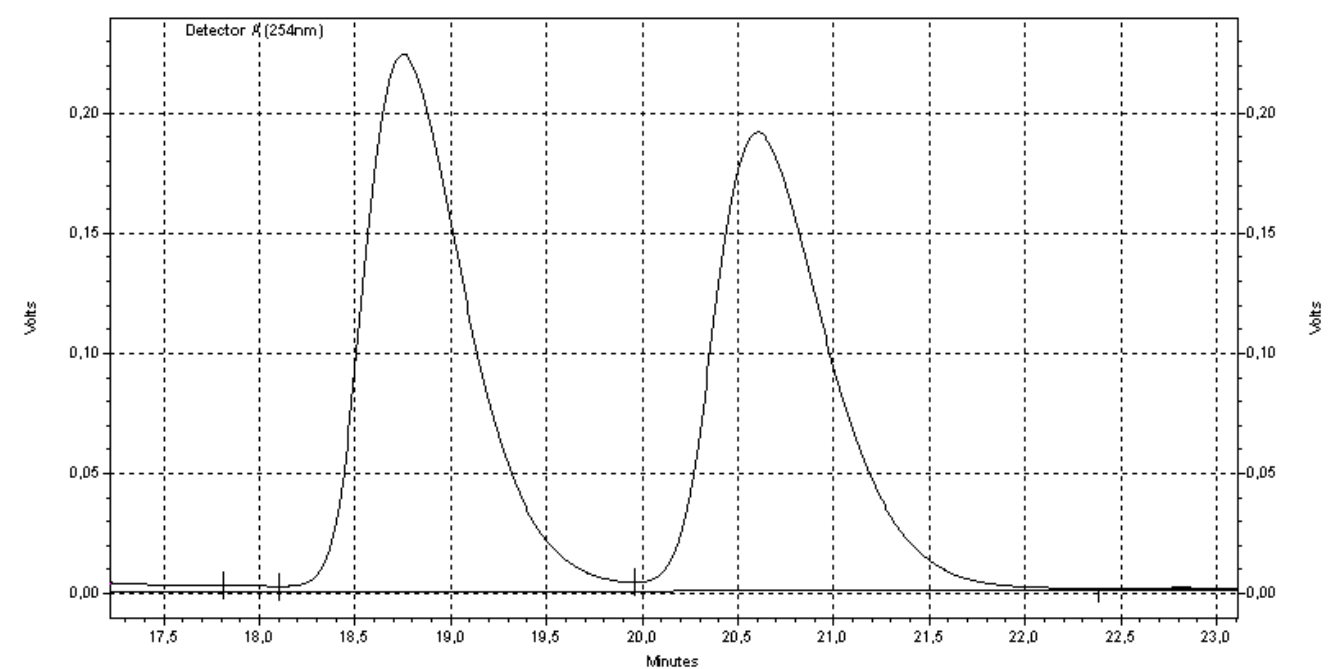

Authentic racemic of sample of phenyl(p-tolyl)methanol using Chiralcel OD as column.

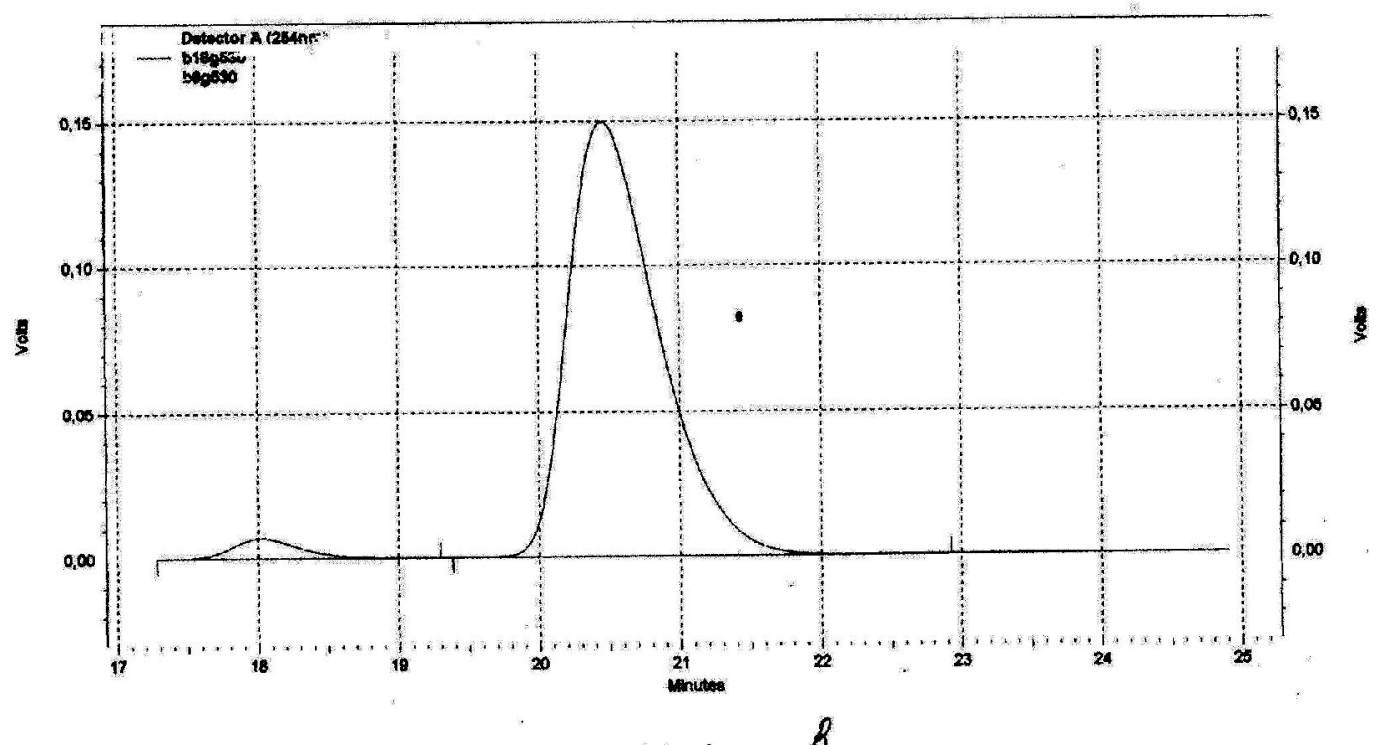

Chiral phase HPLC chart of phenyl(p-tolyl)methanol obtained with catalyst 1 (Table 1, entry 1). 


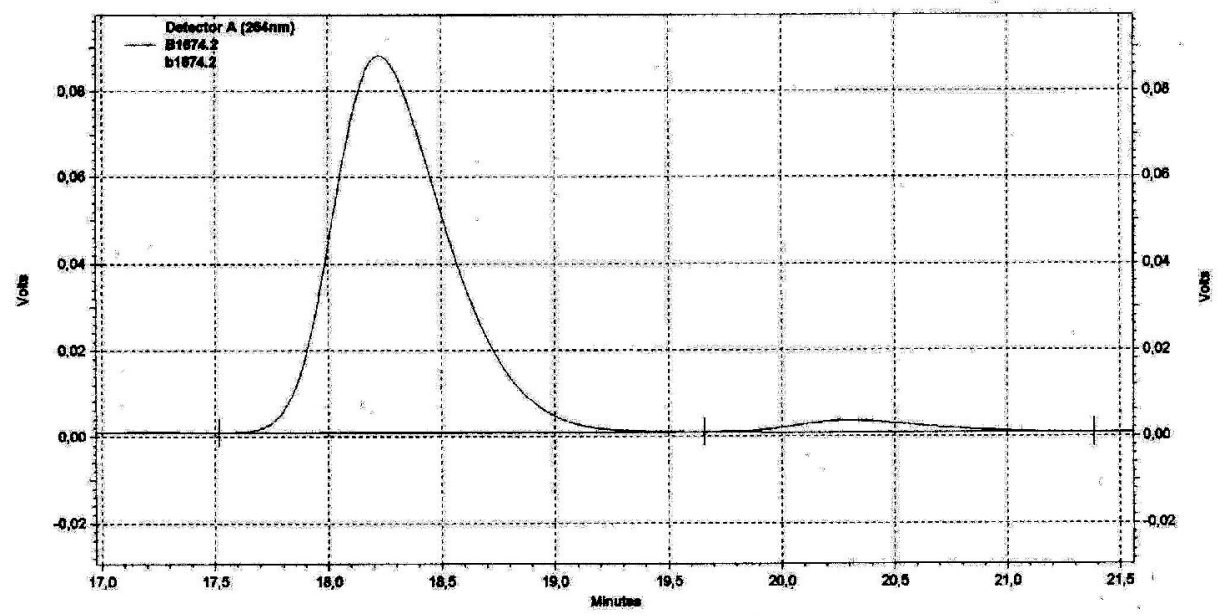

Chiral phase HPLC chart of phenyl(p-tolyl)methanol obtained with catalyst 2 (Table 1, entry 2). 


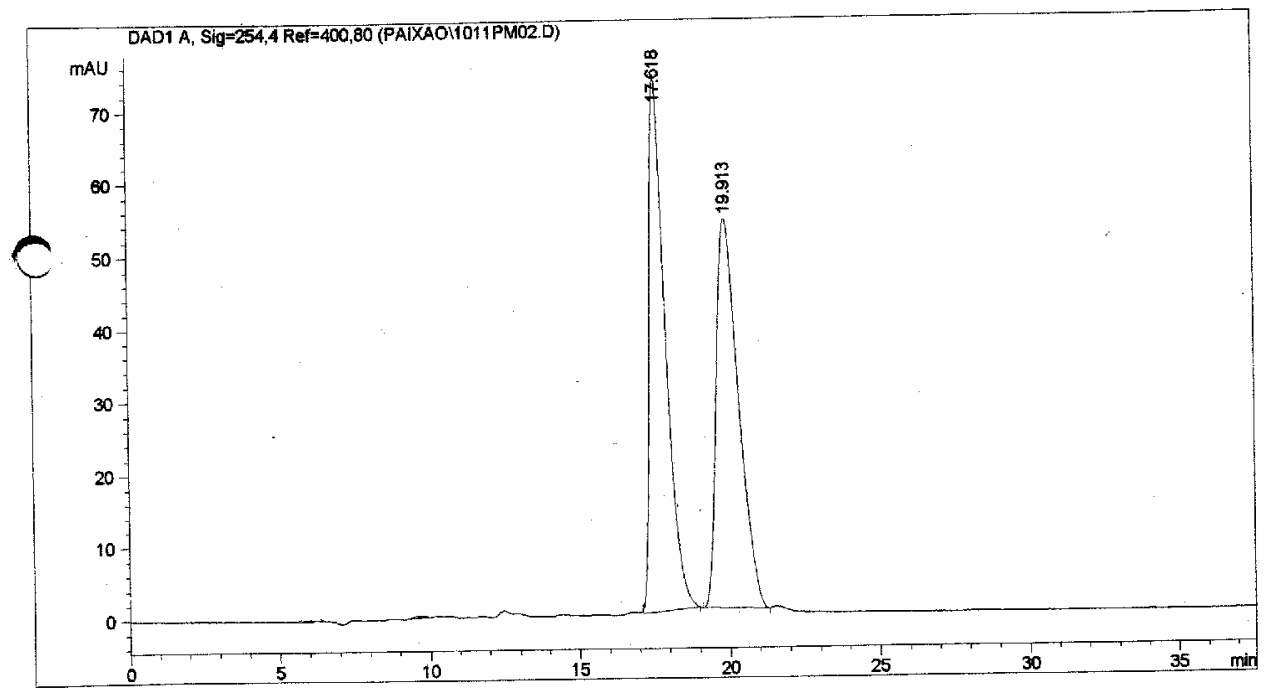

Authentic racemic of sample of phenyl(p-tolyl)methanol using Chiralcel OD-H as column.

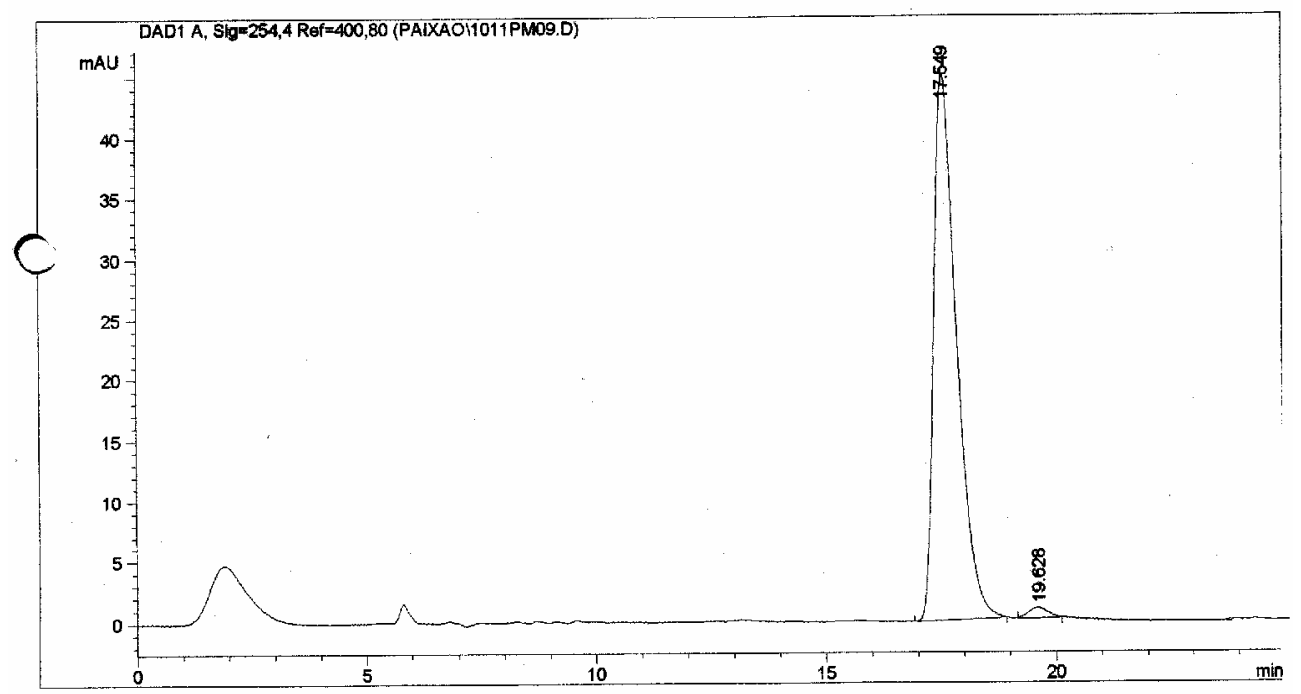

Chiral phase HPLC chart of phenyl(p-tolyl)methanol obtained with catalyst 3a (Table 1, entry 3 ). 


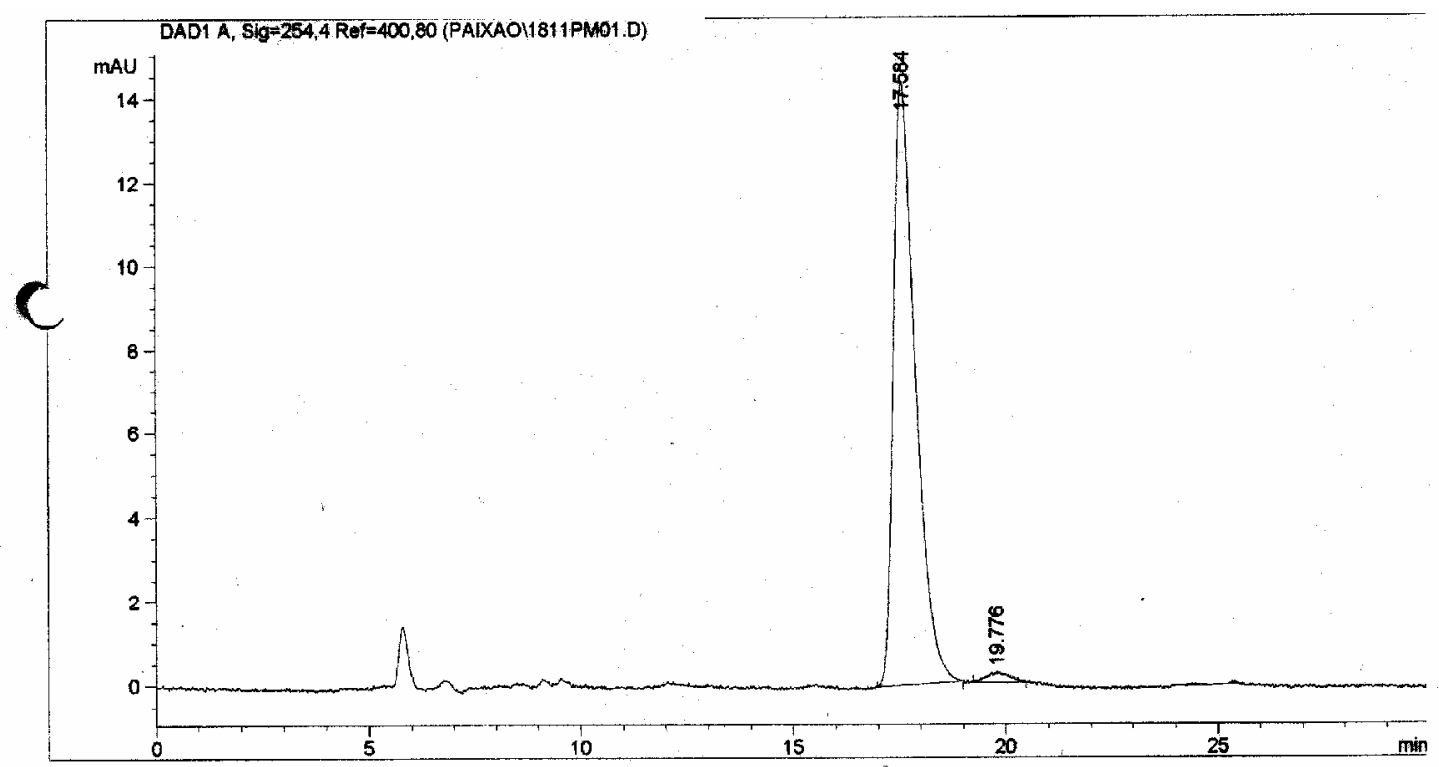

Chiral phase HPLC chart of phenyl(p-tolyl)methanol obtained with catalyst 3a under microwave irradiation (Methold A, Table 2, entry 1).

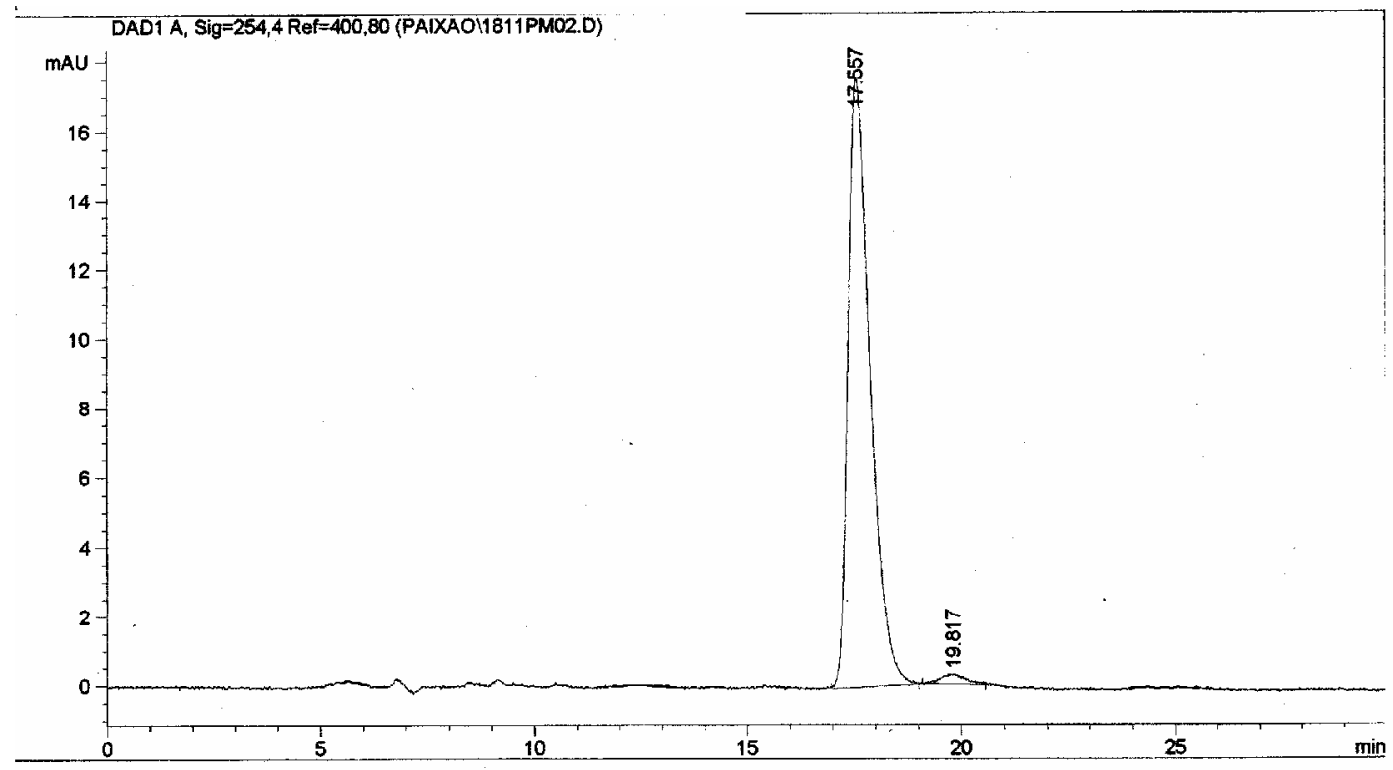

Chiral phase HPLC chart of phenyl(p-tolyl)methanol obtained with catalyst $\mathbf{3 a}$ under microwave irradiation (Methold A, Table 2, entry 2). 


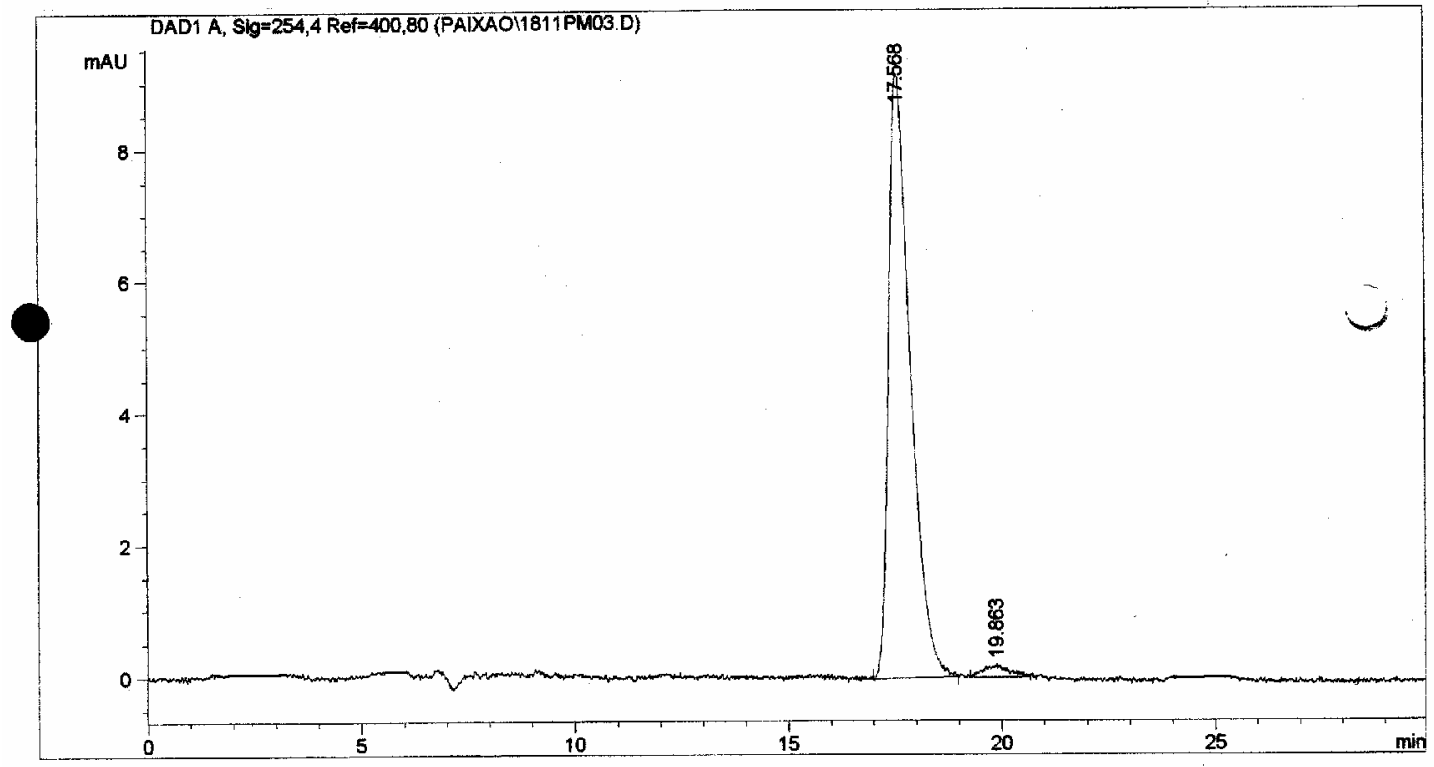

Chiral phase HPLC chart of phenyl(p-tolyl)methanol obtained with catalyst $\mathbf{3 a}$ under microwave irradiation (Methold A, Table 2, entry 3).

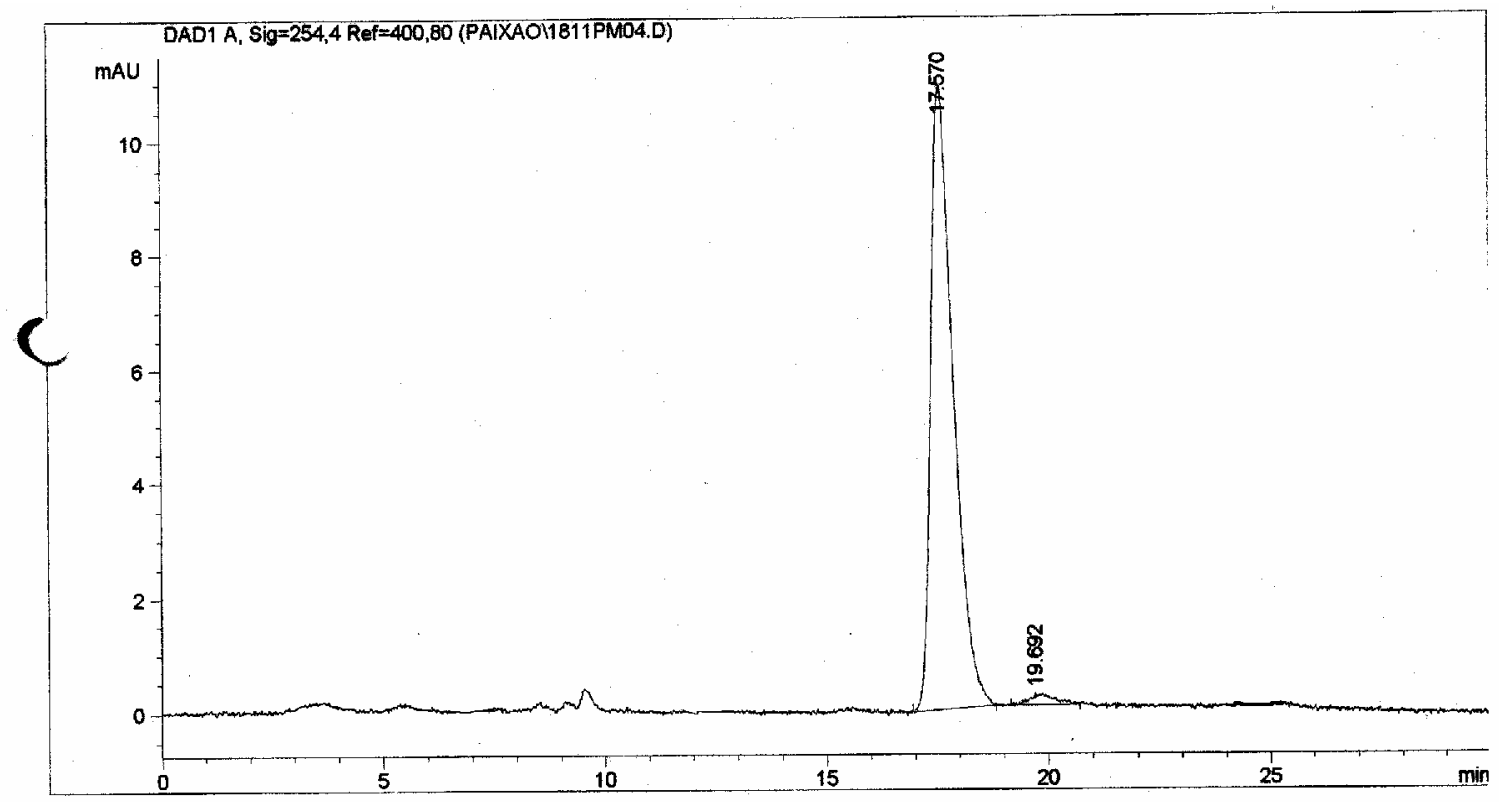

Chiral phase HPLC chart of phenyl(p-tolyl)methanol obtained with catalyst 3a under microwave irradiation (Methold A, Table 2, entry 4). 


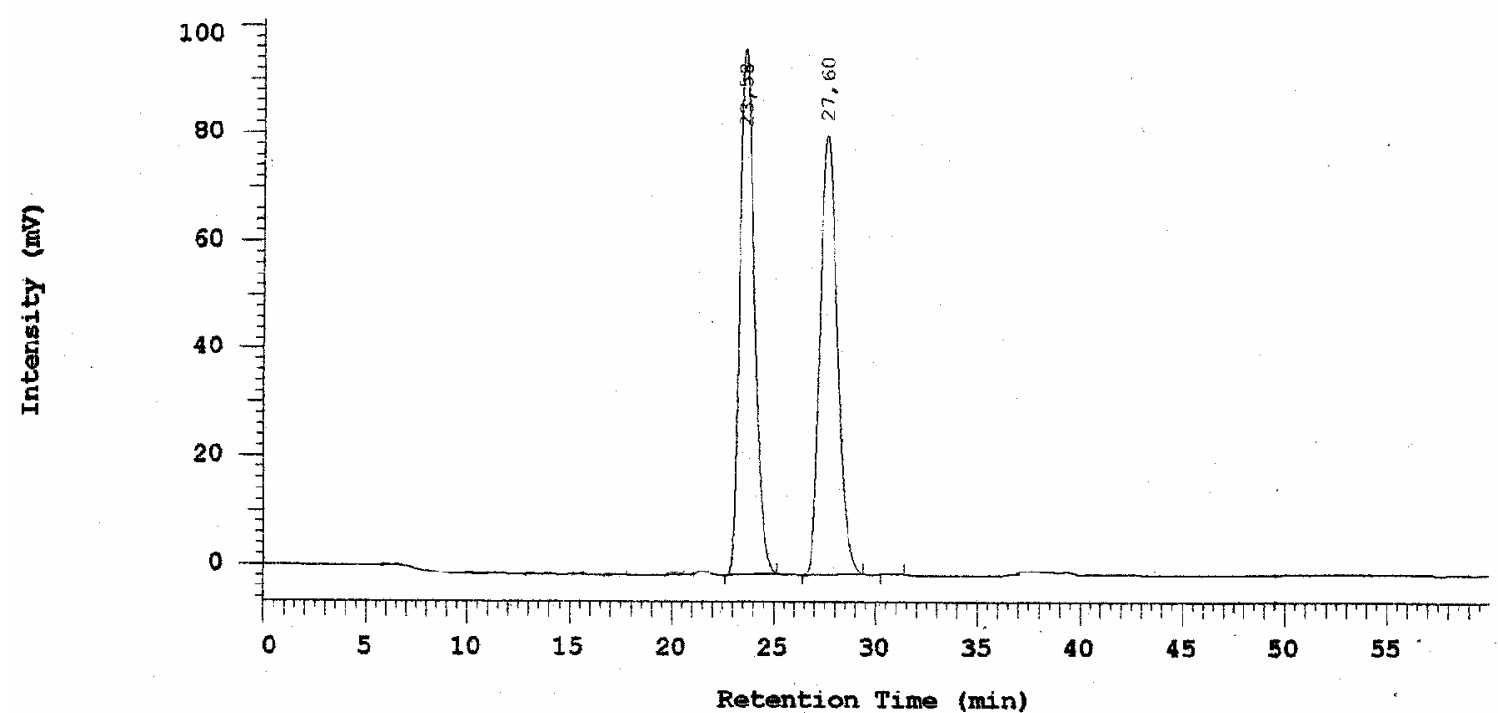

Authentic racemic sample of phenyl(p-tolyl)methanol using Chiralcel OB-H as column.

Chrom Type: HPLC Channel : 1

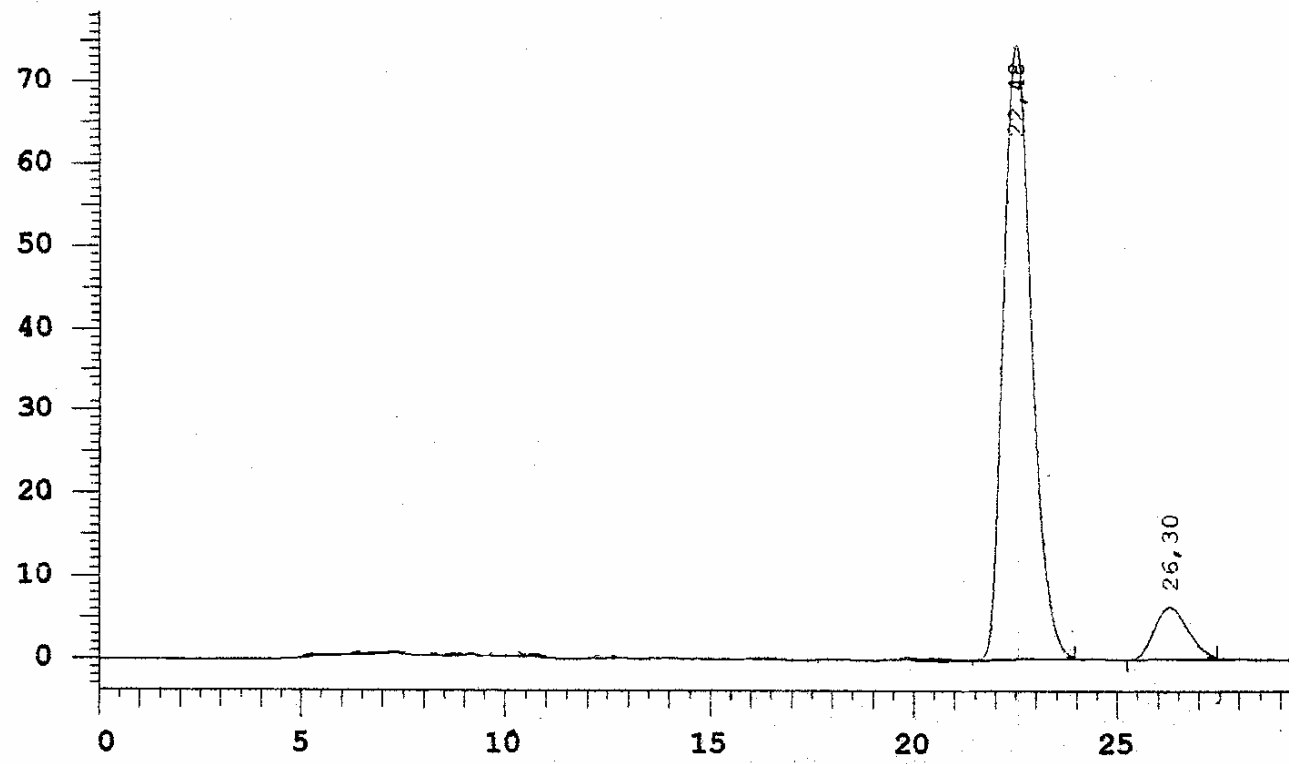

Chiral phase HPLC chart of phenyl(p-tolyl)methanol obtained with catalyst 3a under microwave irradiation (Methold B, Table 2, entry 6). 


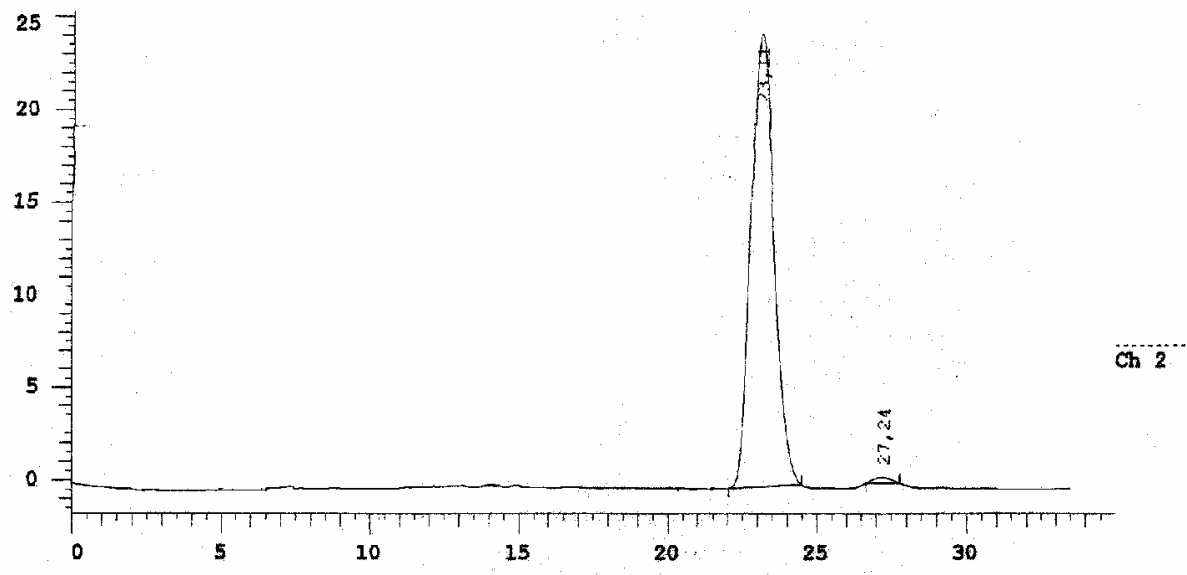

Chiral phase HPLC chart of phenyl(p-tolyl)methanol obtained with catalyst 3a under microwave irradiation (Methold B, Table 2, entry 7 ).

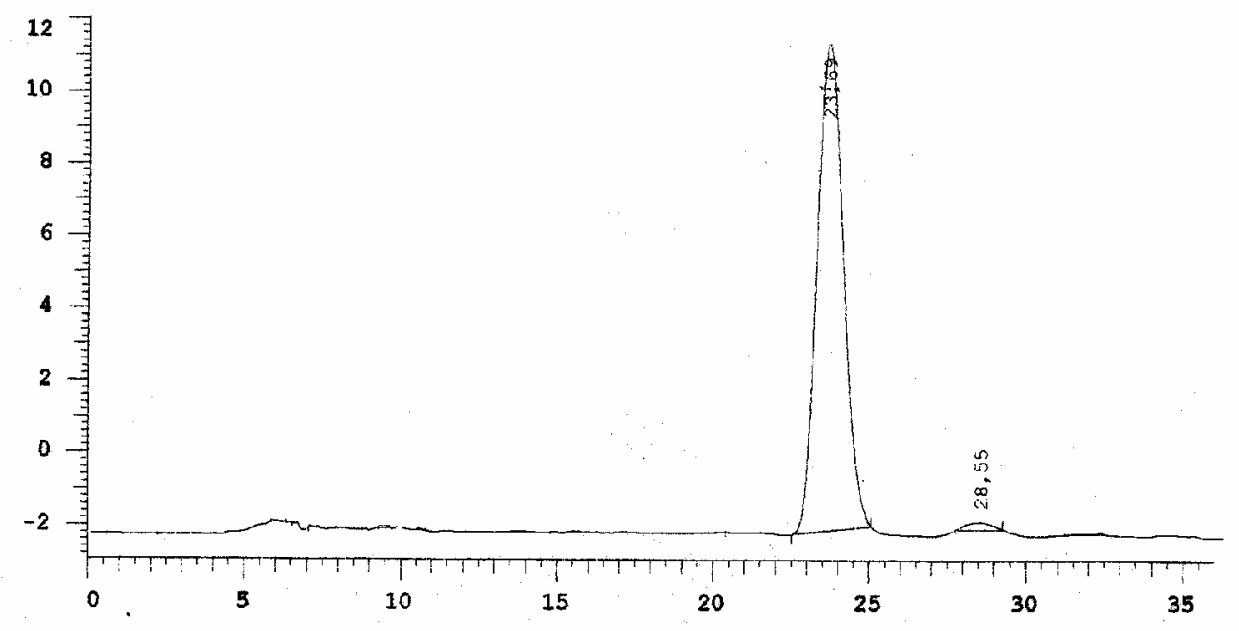

Chiral phase HPLC chart of phenyl(p-tolyl)methanol obtained with catalyst 3a under microwave irradiation (Methold B, Table 2, entry 8). 


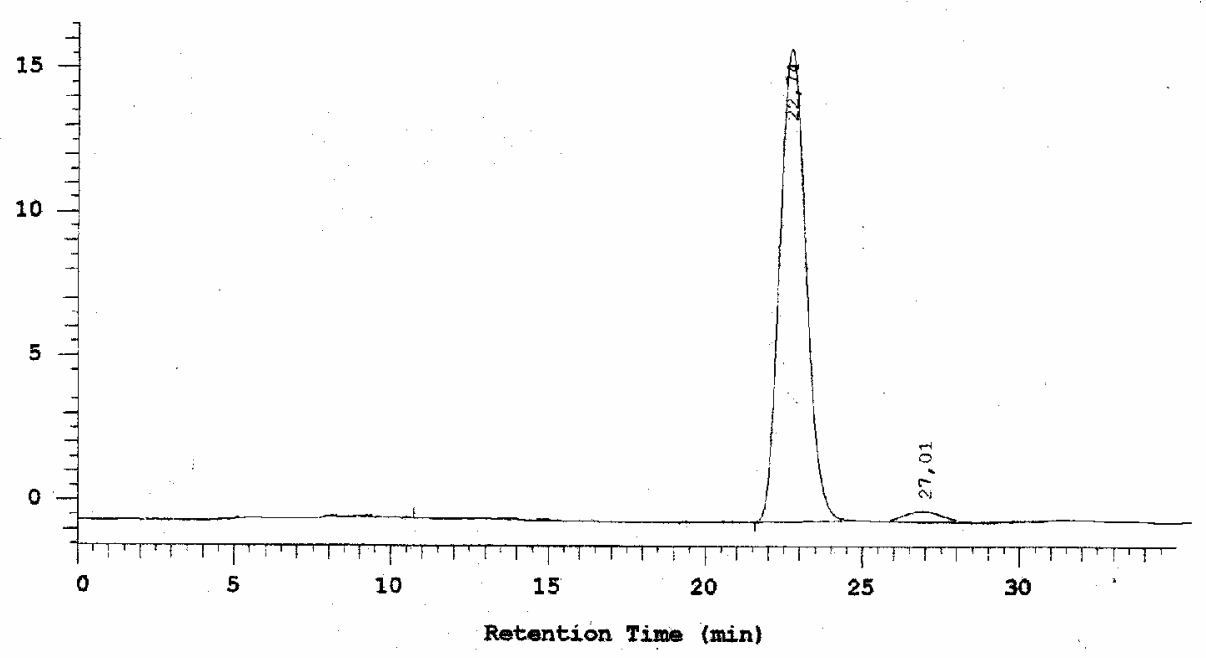

Chiral phase HPLC chart of phenyl(p-tolyl)methanol obtained with catalyst 3a under microwave irradiation (Methold B, Table 2, entry 9) 